\title{
The forest transition in São Paulo, Brazil: historical patterns and potential drivers
}

\author{
$\underline{\text { Adriane Calaboni }}^{1}, \underline{\text { Leandro R. Tambosi }}^{2}, \underline{\text { Alexandre T. Igari }}^{3}, \underline{\text { Juliana S. Farinaci }}^{4}, \underline{\text { Jean Paul Metzger }}^{1}$ and Maria Uriarte $^{5}$
}

\begin{abstract}
Agricultural expansion has caused extensive deforestation throughout the tropics in the last decades, nevertheless, some countries have experienced native forest gains. In the 20th century, the state of São Paulo, Brazil, transitioned from an agricultural frontier to an agro-industrial state, and in parallel, from a high deforestation rate to a net gain in native forest. Here we examine the biophysical and socioeconomic factors that best explain land use and forest cover change in the state, at the municipality scale, over four consecutive intervals between 1960 and 2006. We hypothesized that factors that increase the productivity of agricultural land or reduce pressure on land development would lead to regeneration. Although results differed among intervals, our analyses demonstrate that forest gains were greater in municipalities with high forest cover percentage and steep slopes, and in areas that employed a large number of workers and relied on intensive fertilizer inputs. At the same time, forest loss was higher in municipalities with a large portion of agricultural land and soils with higher water retention capacity. These results reveal that land-use expansion led to forest loss in areas more suitable for agriculture, while forest gains occurred mainly in less suitable areas. Over time, agricultural expansion leveled off and agriculture intensification enabled forest gains, which were most marked in areas with a high percentage of forest remnants. Ultimately, however, these proximate drivers of forest change were driven by governmental policies to modernize agriculture and to protect natural ecosystems.
\end{abstract}

Key Words: agriculture modernization; forest cover change; land-use change; São Paulo

\section{INTRODUCTION}

Agricultural expansion throughout the tropics in the 1980s and 1990s occurred mainly at the expense of forests (Gibbs et al. 2010). Currently, large-scale commercial agriculture is the most important driver of deforestation in the tropics (DeFries et al. 2010, Hosonuma et al. 2012, Rudel 2015). The magnitude and pervasiveness of tropical deforestation over the past three decades has led to food insecurity, high pest pressure, biodiversity loss, reduced availability of clean water, depleted soils, and increased vulnerability to climate extremes (Foley et al. 2005). At the same time, however, some developing countries, including some regions of Brazil (Baptista 2008, Silva et al. 2016, Costa et al. 2017, Molin et al. 2017), have lessened the pressure of agriculture expansion on forests (Lapola et al. 2014). Understanding the patterns of forest change and the underlying causes is fundamental to the development of policies that ensure biodiversity preservation, climate regulation, and the support of human populations.

Multiple drivers that act synergistically lead to tropical deforestation by influencing land use directly (proximate causes) and indirectly (underlying driving forces; Geist and Lambin 2002). Human activities, including expansion of agricultural lands, wood extraction, infrastructure development, and changes in disturbance regimes are the proximate causes of forest loss and degradation (Geist and Lambin 2002). Ultimately, however, human decisions are driven by underlying forces such as demand growth in local and international markets for agricultural and timber products, technological advances, agriculture development policies, industrialization, and urbanization (Geist and Lambin 2002). For example, deforestation at the global scale has been related to agricultural expansion to supply the growing urban populations through expanding local and global markets (DeFries et al. 2010).

Despite forest losses in many areas of the tropics, a growing number of studies document cases of large-scale forest regeneration (Rietbergen-McCracken et al. 2007, Brancalion et al. 2016, Chazdon and Guariguata 2016). Tropical countries like Costa Rica, Puerto Rico, Nicaragua, South Korea, Vietnam, Guatemala, and Mexico, among others, have experienced net gains in forest cover over the last decades (Chowdhury 2007, Parés-Ramos et al. 2008, Crk et al. 2009, Yackulic et al. 2011, Redo et al. 2012, Aide et al. 2013). This shift from deforestation to reforestation is explained by forest transition theory, the idea that as a nation develops economically its forest cover declines; as long as development becomes less dependent on the primary sector, e.g., timber extraction, agriculture, and cattle ranching, deforestation tends to halt or even reverse. The transition occurs when regeneration rate exceeds the deforestation rate, leading to net forest gain (Mather and Needle 1998, Rudel et al. 2005).

Particular chains of events, which vary spatially and temporally, can lead to a shift from deforestation to reforestation. The supply decline of ecosystem services and goods provided by native forests, for example, encourage economic incentives that can induce landowners to slow down or halt agriculture expansion (Lambin and Meyfroidt 2010). Law enforcement also contributes to the protection of important or irreplaceable natural areas (Meyfroidt et al. 2014). On the other hand, agricultural modernization promotes the widespread use of fertilizers, pesticides, and machinery, practices that can increase land and labor productivity and make economically feasible a reduction

${ }^{1}$ Departamento de Ecologia, Instituto de Biociências, Universidade de São Paulo, SP, Brasil, ${ }^{2}$ Centro de Engenharia, Modelagem e Ciências Sociais Aplicadas, Universidade Federal do ABC, Santo André, SP, Brasil, ${ }^{3}$ Escola de Artes, Ciências e Humanidades, Universidade de São Paulo, São Paulo, SP, Brasil, ${ }^{4}$ Centro de Ciência do Sistema Terrestre, Instituto Nacional de Pesquisas Espaciais, São José dos Campos, SP, Brasil, ${ }^{5}$ Department of Ecology, Evolution \& Environmental Biology, Columbia University, New York, NY, United States of America 
on cultivated area and abandonment of marginal lands (Mather and Needle 1998, Grau and Aide 2008, Barretto et al. 2013).

Biophysical factors are also important determinants of land-use change influencing both forest cover loss and gain. Regeneration is more likely to occur in areas that face low opportunity costs from agriculture or other extractive land uses. For example, the probability of regeneration is higher on lands distant from dense urban areas and roads, on steep slopes, rocky terrain, and in low fertility soils (Silva et al. 2007, Teixeira et al. 2009, Yackulic et al. 2011, Rezende et al. 2015). Because the majority of tropical forest trees are dispersed by animals, forest remnants are also critical determinants of regeneration potential as they provide habitat for pollinators and seed dispersers (Thomlinson et al. 1996, Holl 1999). Conversely, deforestation is more likely near roads, human settlements, and fertile lands (Freitas et al. 2010, 2013).

Despite these general patterns, natural regeneration or deforestation is largely influenced by cultural, institutional, or economic contexts (Perz 2007, Chazdon and Guariguata 2016). Thus, countries or regions exhibit complex forest transition trajectories that are contingent on their socioeconomic, political, and development histories (Lambin and Meyfroidt 2011, Redo et al. 2012). Forest transitions in developed countries were largely driven by industrialization policies that encouraged rural-urban migration, concentration of modern agriculture on flatter and fertile lands, i.e., agricultural adjustment, and abandonment of marginal lands (Rudel et al. 2005), while in many developing countries forest transitions have been associated with agricultural intensification, productivity increase, and marginal land abandonment (Grau and Aide 2008).

In Brazil, land-use intensification has been associated with the expansion of agricultural lands and deforestation in central and north regions; nevertheless, land-use intensification has also been associated with farming stability and forest regeneration in agriculturally consolidated areas, in southern and southeastern regions (Barretto et al. 2013). In parallel, studies showed that land-use intensification and marginal land abandonment are related to forest gains in the state of São Paulo, southeastern Brazil (Farinaci 2012, Silva et al. 2016, Molin et al. 2017). Thus, it seems that the relationship between agricultural expansion and deforestation has been weakened in the state, indicating an underlying forest transition (Farinaci 2012, Barretto et al. 2013, Lapola et al. 2014, Silva et al. 2016, Molin et al. 2017).

In the 20th century the most developed Brazilian state, São Paulo, transitioned from an agricultural frontier to an agro-industrial state, and in parallel, from a high deforestation rate to net gains in native forest. Here we examine land use dynamics in the state to deepen our understanding of the factors related to forest transition in the tropics. To do so, we assessed historical patterns of forest cover change in the state between 1960 and 2006 together with the socioeconomic and biophysical factors associated with forest cover loss and gain. Because the drivers of forest cover change shift over time (Silva et al. 2016), we investigate the change over four consecutive periods: 1960-1970, 1970-1980, 1980-1996, and 1996-2006. Socioeconomic and biophysical factors for analyses were chosen based on studies in São Paulo (Silva et al. 2016, Molin et al. 2017) and elsewhere in the tropics (Crk et al. 2009, Yackulic et al. 2011) and were informed by knowledge of the state land-use history. We ask the following: (1) What are the patterns of deforestation and forest regeneration across the state over the four consecutive periods? (2) What factors drive forest gains and losses? We hypothesize that factors that increase the productivity of agricultural land or reduce pressure on land development will lead to regeneration. Hypotheses associated with each factor are provided in Table 1.

\section{METHODS}

\section{Study site}

The state of São Paulo covers 24.6 million hectares (3\% of Brazilian territory; Fig. 1) and comprises 645 municipalities with a total population of 41.3 million people $(21.6 \%$ of the country's population, IBGE 2011). During the 20th century, the state shifted from an agricultural frontier to an agro-industrial developed state, and from a high deforestation rate to net gains in native forest by the end of the 20 th century.

Fig. 1. The state of São Paulo, Brazil (A), and the 645 municipalities analyzed in this study (B).
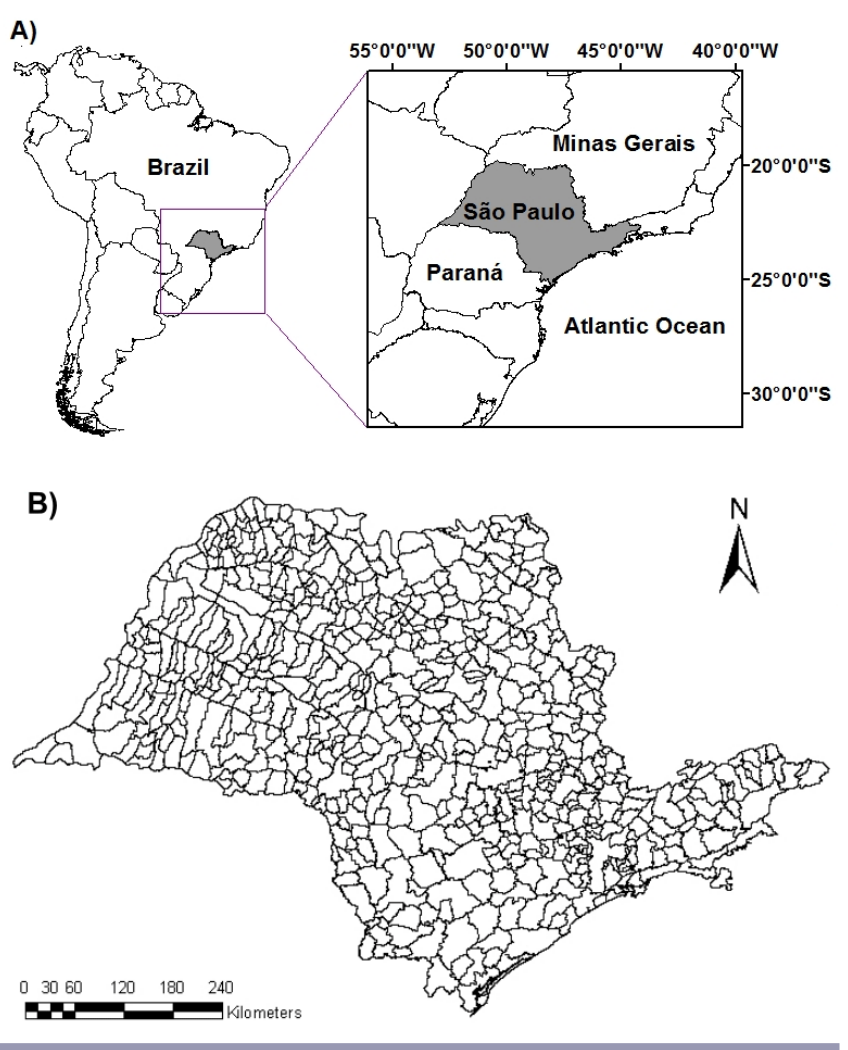

The industrialization of agriculture in São Paulo after 1960 was driven by the creation of several government programs (Fig. 2) that particularly favored the state agro-industry. The Military Government (1964-1985) invested in agriculture modernization by creating the Rural Credit Subsidy System (RCSS) in 1965, which provided subsided loans for agriculture modernization. In 1972, the Brazilian Agricultural Research Corporation (EMBRAPA) was created to develop advanced agricultural technologies, including those customized for production on the different Brazilian Biomes. One year later, in 1973, the National Program of Alcohol (PROÁLCOOL) was implemented with the 
Table 1. Explanatory variables considered in the models and hypothesized relationship between forest cover change and each of the drivers. The hypothesized relationship is indicated as positive (+) when the driver is expected to be associated with forest gains or negative (-) if associated with forest loss. All explanatory variables were included in the models as a ratio to account for drivers' variation during each of the time periods (1960-1970, 1970-1980, 1980-1996, and 1996-2006), except for slope, soil water retention capacity, and percentage of forest cover at the start of the interval.

\begin{tabular}{|c|c|c|c|}
\hline $\begin{array}{l}\text { Explanatory } \\
\text { Variables }\end{array}$ & & $\begin{array}{c}\text { Hypothesized } \\
\text { Relationship }\end{array}$ & $\begin{array}{l}\text { Rationale } \\
\text { for hypothesis }\end{array}$ \\
\hline \multirow[t]{8}{*}{ Socioeconomic } & Density of farm workers & - & $\begin{array}{l}\text { Nonfarm jobs lead rural-to-urban migration decreasing } \\
\text { density of workers and leading to land abandonment (Rudel } \\
\text { et al. 2005) }\end{array}$ \\
\hline & Pasture (extensive livestock) & - & $\begin{array}{l}\text { Low-productivity cattle ranching occupies as much area as } \\
\text { possible, promoting deforestation }\end{array}$ \\
\hline & Uncultivated lands & + & $\begin{array}{l}\text { Agriculture concentrates in the most suitable regions and } \\
\text { unprofitable lands are abandoned (Lambin and Meyfroidt } \\
\text { 2010). }\end{array}$ \\
\hline & Annual crops & - & $\begin{array}{l}\text { Annual crops such as soybean and sugarcane were } \\
\text { economically important between } 1960 \text { and } 2006 \text { and } \\
\text { expanded significantly during that period (Chabaribery } \\
\text { 1999) }\end{array}$ \\
\hline & Perennial crops & + & $\begin{array}{l}\text { More permanent land use has lower negative impact on } \\
\text { forest cover }\end{array}$ \\
\hline & Exotic tree plantation & + & $\begin{array}{l}\text { Managed tree plantations can facilitate forest recovery } \\
\text { because of environmental certification that demands } \\
\text { environmental law compliance (Silva et al. 2016) }\end{array}$ \\
\hline & Establishments that used fertilizer & + & $\begin{array}{l}\text { Land-saving practices can reduce the demand for new } \\
\text { cleared land (Barretto et al. 2013) }\end{array}$ \\
\hline & Tractors per area & + & $\begin{array}{l}\text { Improving agricultural technology increases production and } \\
\text { decreases the demand for land (Barretto et al. 2013) }\end{array}$ \\
\hline \multirow[t]{4}{*}{ Biophysical } & & & \\
\hline & Mean slope & + & $\begin{array}{l}\text { Steeper slopes are more likely to regenerate (Silva et al. } \\
\text { 2007, Teixeira et al. 2009) }\end{array}$ \\
\hline & Water retention capacity of soil & - & $\begin{array}{l}\text { Soils with higher water retention capacity are more likely } \\
\text { occupied by agriculture }\end{array}$ \\
\hline & $\begin{array}{l}\text { Forest cover at the start of the } \\
\text { interval }\end{array}$ & + & $\begin{array}{l}\text { Close proximity to seed sources facilitates native forest } \\
\text { regrowth (Holl 1999) }\end{array}$ \\
\hline
\end{tabular}

aim of fostering research on the development of biofuels as an alternative to rising oil prices (Navarro 2010).

Such programs and policies facilitated the expansion of export crops (Carvalho and Silva 1987), mechanization of agriculture (Camargo and Santos 1985), and significant increases in fertilizer and pesticide use (Ferreira et al. 1986, Chabaribery 1999) in the state. These changes also fostered high rates of rural-urban migration in São Paulo because of the growing unemployment rates in rural areas, leading to a decrease in rural population across the state from $43 \%$ in $1950,31 \%$ in $1960,21 \%$ in 1970 , to $14 \%$ in 1980 (Veiga and Otani 1983). Rural populations migrated to urban centers seeking job opportunities in a growing industrial sector that was in accelerated development in the state from 1950's onwards (Veiga and Otani 1983, Garcia 1986, Ghilard 1986). Consequently, near $96 \%$ of the 41.3 million inhabitants of São Paulo live in urban centers (IBGE 2011).

On the other hand, important environmental institutions and policies were created in the second half of the 20th century (Fig. 2). The Brazilian Government created the Brazilian Forest Code (BFC) in 1965 that required landowners to maintain a percentage of their properties in native vegetation and also to preserve native vegetation on slopes steeper than $45^{\circ}$, hilltops, and riparian areas. The Brazilian Government also created environmental agencies over this period, namely the National Council of Environment (CONAMA) in 1981 and the Brazilian Institute of Environmental and Natural Resources (IBAMA) in 1989. Additionally, the state of São Paulo created the State Council of Environment (CONSEMA) in 1983.

As a consequence of centuries of intense occupation and agricultural growth, however, the Atlantic Forest in São Paulo retains only $16.2 \%$ of its original cover (SOS/INPE 2015) and most remnant forest patches are scattered and fragmented (Ribeiro et al. 2009), whereas Cerrado retains about $4 \%$ of its original cover (Kronka et al. 2005). Nevertheless, recent assessments indicate a marked reduction of deforestation since 1985 (Lira et al. 2012, SOS/INPE 2015) and a net increase of native forest cover at the state scale (Farinaci and Batistella 2012). Studies at the landscape scale have demonstrated that forest gains in the state are concentrated in areas far from roads and major cities and on steeper slopes (Teixeira et al. 2009, Freitas et al. 2010, 2013).

Studies at state scale, however, use aggregate data that hide important variation in finer scales, such as municipality scale. Analyses at finer scales are necessary if we are to understand the socioeconomic factors that underlie long-term forest cover change in São Paulo. 
Fig. 2. Temporal variation in total forest cover percentage (A), farm factors (B and C), and land use (D and E) at the state scale, and the main political and economic events during the study period (1960-2006). Percentages were calculated by dividing the total area of the specific land use in the state of São Paulo by the sum of the area of all the rural establishments in the state. Similarly, the density of workers on farms and number of tractors per area were calculated by dividing the total number of tractors/worker on farms in the state of São Paulo by the sum of the area of all the rural establishments in the state. Main government programs are the National Program of Alcohol (PROÁLCOOL), Brazilian Agricultural Research Corporation (EMBRAPA), the National Council of Environment (CONAMA), São Paulo State Council of Environment (CONSEMA), and the Brazilian Institute of Environmental and Natural Resources (IBAMA).
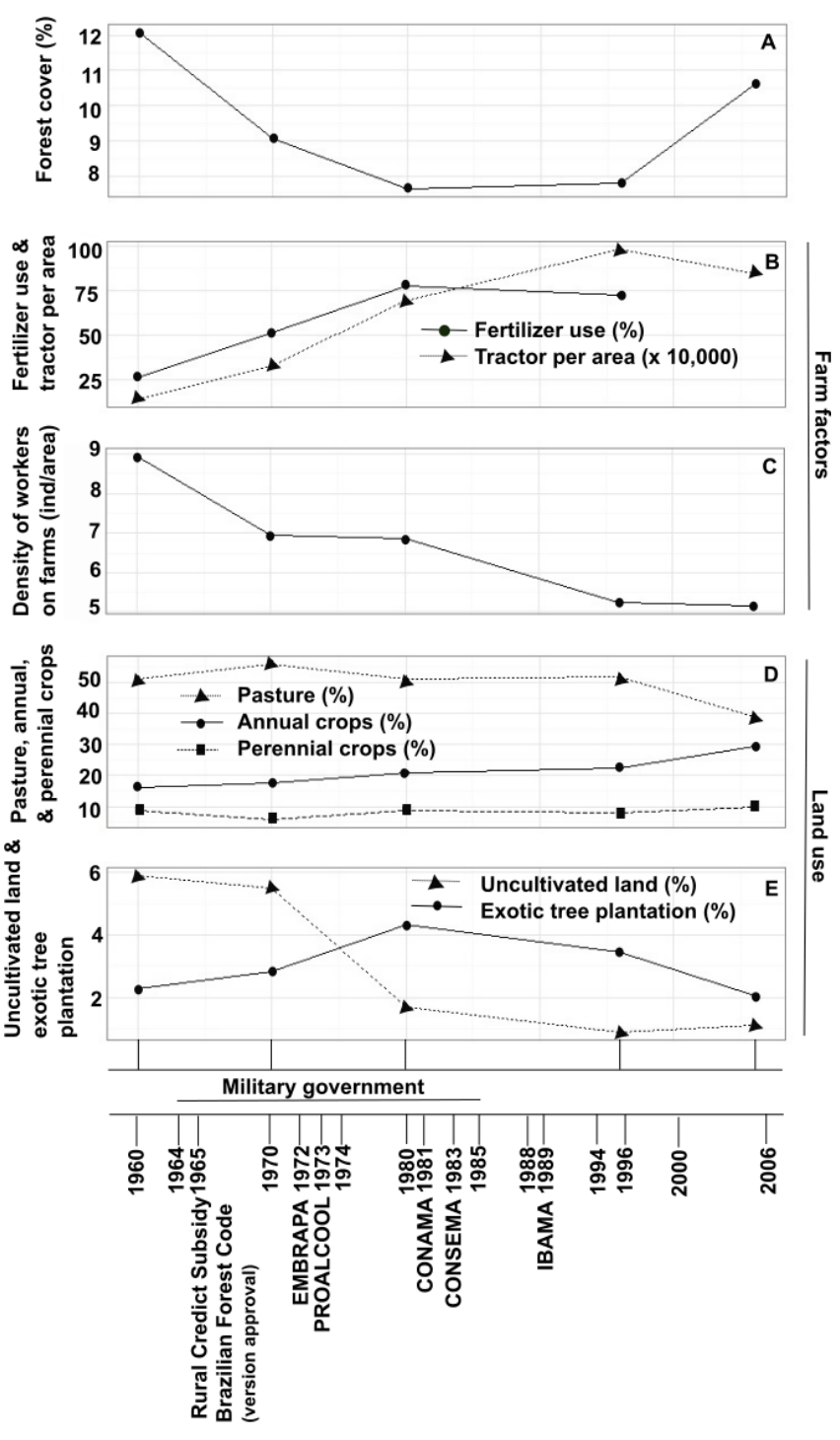

Data

Forest cover and socioeconomic data are at municipality scale and were obtained from the Brazilian National Agrarian Census Surveys (IBGE - Brazilian Institute of Geography and Statistics) for the years 1960, 1970, 1980, 1996, and 2006. IBGE data are available at SIDRA database (https://sidra.ibge.gov.br/acervo\#/ $\underline{\mathrm{S} / \mathrm{Q})}$. The Agrarian Census Survey was conducted only on private properties with some agriculture activity, e.g., agriculture, forestry, or aquaculture in rural and urban areas, excluding conservation units. Surveys were conducted by interviewing landowners and managers, but data were not available at the property-level for confidentiality reasons. A spatially explicit approach was not used in the present study due to the lack of satellite data for the entire state with all the land-use classes and for all the years considered in the analyses. Nevertheless, a comparison between the estimates of forest cover from IBGE and estimates from satellite imagery showed that they are highly correlated (Calaboni 2017).

Percentage of forest cover was calculated by dividing the total forest cover area (ha) of each municipality by the total census area, e.g., municipality area in which the census was taken. IBGE considers forest to be old-growth forests, woodlands, shrubs, and also secondary forests at initial stage of succession.

Socioeconomic variables include density of permanent farm workers, number of tractors per area, and the percentage of farms that used fertilizer. Density of farm workers was calculated by dividing the number of permanent workers on farms by the total census area in the municipality. We also include the percentage of pasture, exotic tree plantations, annual and perennial crops, and uncultivated land in the municipalities. Uncultivated lands are those that have not been planted for more than four years at the time of the census. They also included lands exhausted by erosion, salinization, and desertification.

Biophysical variables included average slope, soil water retention capacity, and percent forest cover at the start of the time interval. Soil water retention capacity for each municipality was derived from the state soil map (scale 1:500.000) created by EMBRAPA (Oliveira et al. 1999). Average slope values for each municipality were calculated using digital elevation data created by the NASA Shuttle Radar Topographic Mission (SRTM) at $90 \mathrm{~m}$ resolution. Elevation data is available at EMBRAPA's web site (https://www. cnpm.embrapa.br/projetos/relevobr/). Forest cover percentage in each municipality at the start of the interval was included to assess the effect of previous forest cover extension on deforestation or regeneration. Appendix 1 provides temporal changes and geographic distributions of all factors included in the analyses.

\section{Statistical analyses}

Forest cover at the end of the interval was used as response variable. We fitted linear mixed-effect models to associate forest cover change to 11 socioeconomic and biophysical factors (Table 1). Forest cover at the end of the interval was log-transformed in order to meet assumptions of normality. We used the ratio of the explanatory variables at the start and end of the census to assess if changes on socioeconomic factors were associated with changes on forest cover between periods. We calculated this ratio by dividing the values in one census by values in the previous census, e.g., pasture in 1970 / pasture in 1960, where values $>1$ indicate that pasture area increased and values $<1$ indicate that pasture 
area decreased. We use percentage of establishments that used fertilizer, instead of ratio, because the data was not available for 2006. All fixed explanatory variables were standardized by subtracting the mean and dividing by one standard deviation (Gelman and Hill 2006). All explanatory variables included in the analyses had pairwise Pearson's correlation coefficients $r<0.4$.

As the socioeconomic development of a municipality may be associated with the development of its neighboring municipalities, thereby introducing spatial autocorrelation in the response variable, we used as random effect São Paulo's microregions. These are sets of neighboring municipalities grouped by IBGE according to socioeconomic similarities. São Paulo's microregions are available at IBGE's web site (http://www.ngb.ibge.gov.

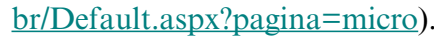

We conducted separate analyses for four different time intervals (1960-1970, 1970-1980, 1980-1996, and 1996-2006). We chose these particular time periods because they encompass the creation of the most important and relevant programs and policies for agriculture development and modernization and environmental protection by the Brazilian and state governments, and the turning point of forest cover change in São Paulo (see Fig 2).

Model selection was conducted separately for each period. Starting with the full model (i.e., all variables in Table 1), we compared all submodels by dropping each of the explanatory variables. For this analysis we used the function "drop1" from the package stats (R Development Core Team 2016a). We used Akaike's Information Criterion (AIC) to select the best model for each period (Burnham and Anderson 2002). This approach allowed us to select a unique set of variables for each period, which we used to test all the possible combinations of explanatory variables for each period. For this analysis, we used the function "dredge" from the package MuMIn (Barton 2016). Models were validated by plotting residuals against fitted values to assess homogeneity and by testing for normality. All analyses were conducted using $\mathrm{R}$ statistical software ( $\mathrm{R}$ Development Core Team 2016b).

\section{RESULTS}

\section{Patterns of change in forest cover}

Between 1960 and 2006, there was a net gain in forest cover in the state of São Paulo. The number of municipalities showing forest regeneration increased steadily over the same period (Fig. 3). In parallel, there was significant temporal and spatial variation in forest cover and dynamics among municipalities. In 1960-1970, forest cover declined in $78.3 \%$ of the municipalities, but it was particularly marked in the western part of the state (Fig. 3). In 1970-1980, forest cover declined in $67.3 \%$ of the municipalities, but deforestation was concentrated in the center and north of the state. In 1980-1996 and 1996-2006, forest cover increased in 67\% and $79.7 \%$ of the municipalities, respectively, leading to a net gain in forest cover at the state scale (Fig. 2A). Despite these gains in forest cover, in 1980, 1996, and 2006 the large majority of São Paulo's municipalities $(94.7 \%, 95.5 \%$, and $94.3 \%$, respectively) had a low percentage $(<30 \%)$ of forest cover (Fig. A1.1).

Spatio-temporal variation in drivers of forest change Visual interpretation of the drivers associated with forest change across the state and through time (see Figs. A1.2-A1.9) showed that changes in the importance of specific drivers across the state and among different intervals were largely consistent with our specific hypotheses (see Table 1), illustrating the effects of agricultural expansion and modernization across the state.

Fig. 3. Forest cover ratio at the municipality-scale across São Paulo between 1960 and 2006. Municipality boundaries are shown in grey. Forest cover ratio was calculated by dividing forest cover values in one census by forest cover values of the previous census (e.g., FC in 1970/FC in 1960). Ratio values greater than 1 indicate that forest cover increased over the census interval and ratio values lower than 1 indicate that forest cover decreased. (NA) Missing values.
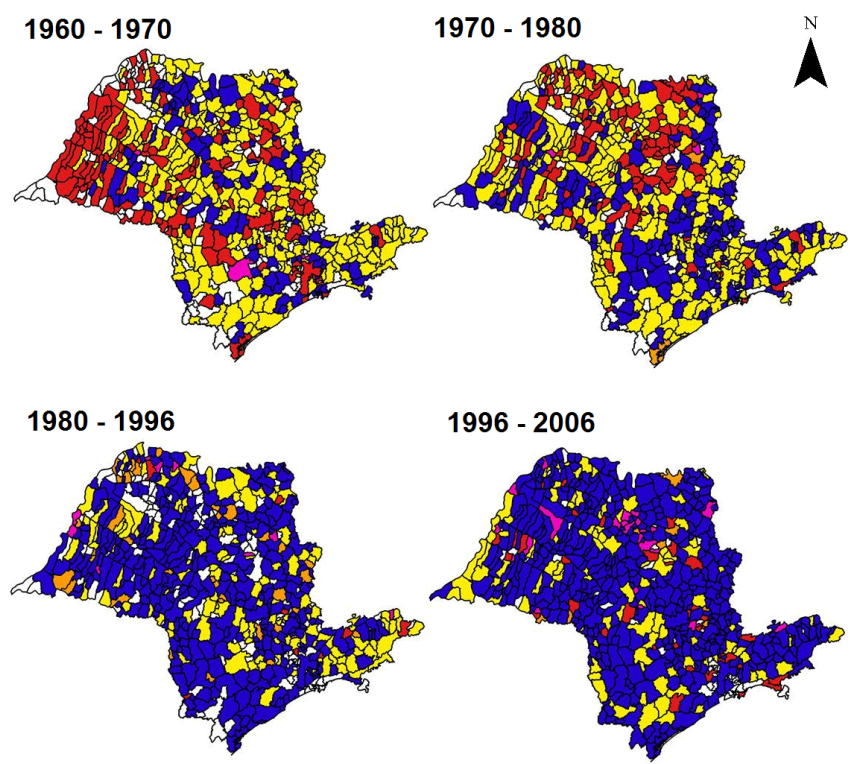

Forest cover (ratio)

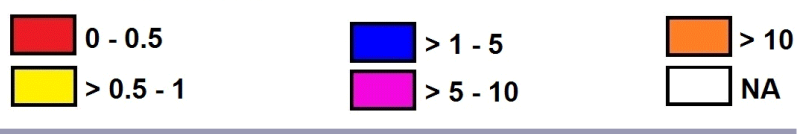

The number of tractors per area and the percentage of farms that used fertilizers increased steadily at the state scale between 1960 and 2006 (Fig. 2B). At municipality scale, the number of tractors per area increased in most of the municipalities in 1960-1970, $1970-1980$, and $1980-1996(96.1 \%, 95.7 \%$, and $83.9 \%$ of the municipalities, respectively; Fig. A1.2). In 1960 and 1970, 76.8\% and $53.6 \%$ of the municipalities, respectively, fewer than $60 \%$ of farms used fertilizer whereas in 1980 and $1996,87 \%$ and $80 \%$ of the municipalities, respectively, more than $60 \%$ of farms used fertilizer (Fig. A1.3). At state and municipality scale, the density of workers on farms decreased steadily between 1960 and 2006 (Fig. 2C and Fig. A1.4).

Over the study period land use varied significantly at municipality scale (Figs. A1.5-A1.9, Table A1.1). The extent of pasturelands at state scale was stable until 1996 and declined between 1996 and 2006 (Fig. 2D). At municipality scale, however, gains in pasturelands occurred mainly in the western region while simultaneously declining in a large portion of municipalities (Fig. A1.5). The extent of perennial crops was stable at state scale while 
Table 2. Akaike information criterion (AIC) and weight for selected models for each time periods (1960-1970, 1970-1980, 1980-1996, 1996-2006). Estimated parameters, standard errors, and $P$-values from the predictors are also provided. All explanatory variables were included in the models as a ratio, except for slope, soil water retention capacity, and percentage of forest cover at the start of the interval.

\begin{tabular}{|c|c|c|c|c|c|}
\hline & Estimated parameters & Standard error & $P$-value & AIC & Weight \\
\hline Model 1960-1970 & & & & 636.8 & 1 \\
\hline Intercept & 1.943 & 0.045 & & & \\
\hline Annual crops & -0.064 & 0.026 & 0.014 & & \\
\hline Perennial crops & -0.059 & 0.022 & 0.007 & & \\
\hline Pasture & -0.053 & 0.025 & 0.03 & & \\
\hline Forest cover in 1960 & 0.377 & 0.033 & $<0.001$ & & \\
\hline Average slope & 0.168 & 0.034 & $<0.001$ & & \\
\hline Soil water retention capacity & -0.076 & 0.025 & 0.002 & & \\
\hline Model 1970-1980 & & & & 633.7 & 0.654 \\
\hline Intercept & 1.746 & 0.032 & & & \\
\hline Pasture & 0.039 & 0.021 & 0.067 & & \\
\hline Forest cover in 1970 & 0.382 & 0.026 & $<0.001$ & & \\
\hline Average slope & 0.239 & 0.027 & $<0.001$ & & \\
\hline Soil water retention capacity & -0.064 & 0.021 & 0.002 & & \\
\hline Model 1980-1996 & & & & 632.7 & 1 \\
\hline Intercept & 1.920 & 0.044 & & & \\
\hline Perennial crops & -0.083 & 0.020 & $<0.001$ & & \\
\hline Pasture & -0.050 & 0.025 & 0.043 & & \\
\hline Forest cover in 1980 & 0.326 & 0.035 & $<0.001$ & & \\
\hline Tree plantation & -0.046 & 0.021 & 0.028 & & \\
\hline Average slope & 0.183 & 0.032 & $<0.001$ & & \\
\hline Soil water retention capacity & -0.046 & 0.022 & 0.039 & & \\
\hline Model 1996-2006 & & & & 360.9 & 1 \\
\hline Intercept & 2.298 & 0.047 & & & \\
\hline Farms that used fertilizer & 0.083 & 0.033 & 0.012 & & \\
\hline Uncultivated land & 0.070 & 0.028 & 0.013 & & \\
\hline Forest cover in 1996 & 0.288 & 0.043 & $<0.001$ & & \\
\hline Tree plantation & 0.066 & 0.028 & 0.022 & & \\
\hline Average slope & 0.197 & 0.046 & $<0.001$ & & \\
\hline
\end{tabular}

the extent of annual crops increased slightly over the study period (Fig. 2D). At municipality scale, perennial crops (Fig. A1.6) increased in $73.2 \%$ and $65.9 \%$ of the municipalities in $1970-1980$ and 1996-2006, respectively, while annual crops (Fig. A1.7) expanded throughout the entire state over the entire study period. The extent of exotic tree plantations was quite stable between $1960-2006$ at the state scale (Fig. 2E) but decreased in 54.9\% and $78.7 \%$ of the municipalities in 1980-1998 and 1996-2006, respectively (Fig. A1.8). Uncultivated lands decreased at state scale (Fig. 2E), although at municipality scale, uncultivated lands declined in $91 \%, 65 \%$, and $89 \%$ of the municipalities in 1970 1980, 1980-1996, and 1996-2006, respectively (Fig. A1.9).

\section{What factors drive forest gains and losses over the study period?}

\section{Biophysical factors}

Forest cover percentage at the start of the interval was positively associated with forest cover at the end of the interval in all census periods (Fig. 4A-D), indicating that higher forest cover, albeit lower than $30 \%$ in most municipalities (Fig. A1.1), facilitated regeneration. In accordance with our expectations, forest regeneration consistently occurred in municipalities with steep slopes (Fig. 4A-D). As we hypothesized, areas with high soil water retention capacity had high rates of forest cover loss between 1960 and 1996 (Fig. 4A-C). However, this was not the case in 19962006 (Fig. 4D) (Table 2).

Most municipalities in São Paulo have soils with higher water retention capacity, flat slopes (Fig. A1.10), and low forest cover (Fig. A1.1). Municipalities with low soil water retention capacity, steep slopes, and high forest cover in those years are concentrated in the coastal region, and in a narrow band that extends from southwestern to northeastern São Paulo. Changes in forest cover across that band of municipalities indicate that until 1980, agriculture expanded also over less suitable lands, but since 1980 these areas have been gradually abandoned (Fig. A1.1 and A1.10).

Effects of land cover change on forest dynamics

We expected expansion of low productivity pasture and annual crops would be associated with forest loss (Table 1). However, increases in the extent of pasture, i.e., high pasture ratios, were associated with forest loss in 1960-1970 and 1980-1996 (Fig. 4A and $4 \mathrm{C}$ ), were nonsignificantly associated with gains in forest cover in 1970-1980 (Fig. 4B), and did not have an effect in forest cover change in 1996-2006 (Table 2 and Fig. 4D). As expected, expansion of annual crops, i.e., high annual crop ratios, was associated with forest cover loss, but only in 1960-1970 (Fig. 4A). 
Fig. 4. Mean parameters estimates (circles) and 2.5-97.5\% confidence intervals (bars) for (A) 1960-1970, (B) 1970-1980, (C) 1980-1996, and (D) 1996-2006. Significance is based on CI values not overlapping zero. Significant effects are shown with filled black symbols and nonsignificant effects are shown with filled grey symbols.

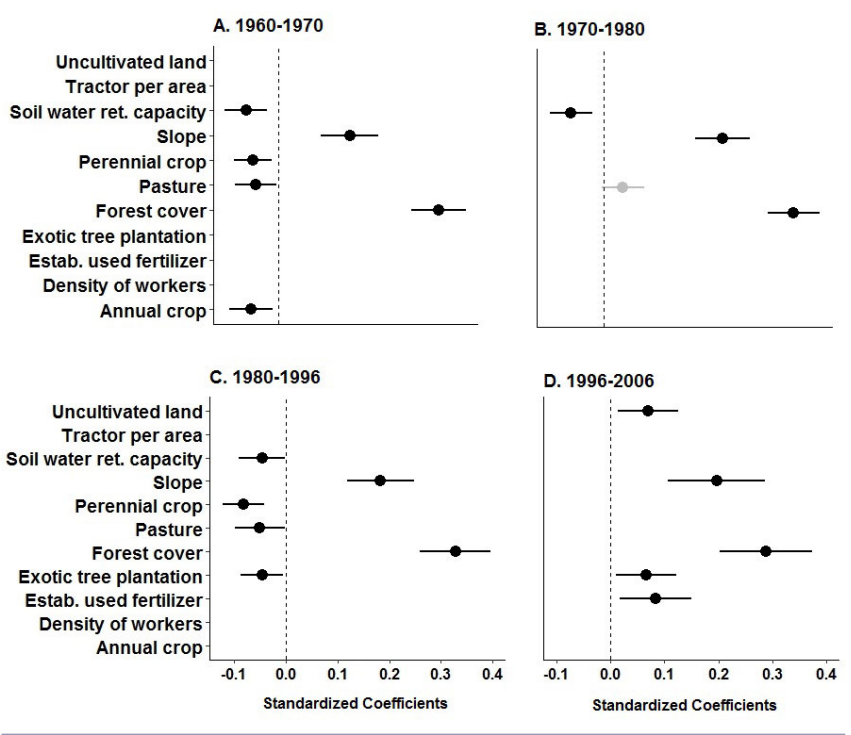

We had also hypothesized that gains in forest cover would be associated with increases of uncultivated, perennial crops or exotic tree plantations, but this was not the case. Expansion of perennial crops, e.g., high perennial crop ratios, was associated with declines in forest cover in 1960-1970 and 1980-1996 (Table 2 and Figs. 4A and C), but it was not an important factor for explaining forest cover change in 1970-1980 or 1996-2006 (Table 2 and Figs. 4B and D). Expansion of exotic tree plantation was positively associated with forest gains in 1996-2006, but negatively associated with forest cover in 1980-1996, contradicting our hypothesis (Figs.4C and D). As expected, increases of uncultivated land were associated with forest gains but only in 1996-2006 (Fig. 4D), showing that lands previously exhausted by agriculture were abandoned during that decade. This pattern, however, was not evident during earlier periods (Table 2).

\section{Farm productivity}

We hypothesized that increases in farm productivity, as reflected in higher tractor or fertilize use, and a decline in the number of rural workers might be related to increases in forest cover (Table 1). As expected, increases in the percentage of farms that used fertilizer were associated with forest cover gains in 1996-2006 (Fig. 4D) but this was not the case for any other period (Table 2). Changes in tractor use and density of permanent workers on farms were not significant predictors of forest cover change in any period (Table 2, Fig. 4).

\section{DISCUSSION}

\section{Change in forest cover and potential drivers}

Until the 1970s the increase in agricultural production resulted primarily from expansion of planted areas (Pino 2016), therefore most of the municipalities in São Paulo experienced forest loss between 1960 and 1980 (Fig. 3). After 1980, however, most of the municipalities exhibited forest gains (Fig. 3), which is probably related to the creation of important agricultural policies in the 1960s and 1970s (Fig. 2). In 1965, the Brazilian government created the Rural Credit Subsidy System (RCSS), which supported development of agriculture support industries, and gave loans to farmers to purchase these products (Baer 2008). The RCSS particularly benefited producers of the most lucrative crops, namely export crops, e.g., soybean, orange, coffee, and sugarcane, that expanded significantly in São Paulo (Veiga and Otani 1983, Garcia 1986, Ghilard 1986, Martins 1986). As a result, there were significant increases in the number of tractors per area (Vicente et al. 1988) and in the percentage of establishments that used fertilizers in the municipalities from the 1960s onward (Martinelli and Filoso 2009), as we observed (see Fig. A1.2-A1.3, Table A1.1). In the long term, increases in agricultural inputs and mechanization led to the increase of land and work productivity (Ghilar 1986, Martins 1986), and possibly encouraged changes in land use and abandonment of marginally productive lands as predicted by Forest Transition Theory (FTT; Mather and Needle 1998). However, the association between factors related to productivity and forest cover increase in the state was only evident in 1996-2006 (see discussion below) possibly due to differences in the stage of the modernization process among São Paulo's municipalities. Such differences possibly delayed the overall effects of productivity increase on forest cover change in the state that only became detectable after 1996.

Nevertheless, the agriculture transformation and forest transition in São Paulo was not accompanied by social development, because Brazilian government policies primarily aimed to expand the agro-industry (Martins 1986). Most rural credits were granted to export crop producers, thus the small and medium farmers that produced mainly staple crops for local markets, e.g., beans, manioc, rice, among others, were excluded from the process of agriculture modernization (Martins 1986). As a result, highly mechanized export crops expanded at the expense of staple crops and many small properties were sold or leased because of the lack of proper policies for small-scale agriculture, which promoted marked land concentration, unemployment in rural areas, high rural-urban migration (Veiga and Otani 1983), and a decrease in the density of permanent workers on farms (Martins 1986; Fig. A1.4, Table A1.1). The rural workforce of São Paulo, however, was not totally absorbed by the other economic sectors in urban areas, as predicted by FTT (Rudel et al. 2005, Lambin and Meyfroidt 2010), a factor that contributed to further increases in unemployment rates in urban centers from 1960 onward (Martins 1986, Vicente et al. 1988).

Land use was very dynamic between 1960 and 2006 in the municipalities of São Paulo (Figs. A1.5-A1.9). However, the aggregate patterns obscured variation in land-use change between decades and across municipalities, hindering our ability to identify patterns of land-use substitution over time in the state. For example, pasture increased in municipalities in the north and west regions (Fig. A1.5) while uncultivated areas decreased in most municipalities in 1970-1980, but increased in 1996-2006, primarily in the western part of the state (Fig. 3E and Fig. A1.6). Our data do not allow us to determine if extensive pasture expanded over uncultivated lands in the north and west regions 
of São Paulo in 1970-1980 or if pasture abandonment in 19962006 led to the increase of uncultivated lands. Nevertheless, we can examine the degree to which shifts in forest cover in municipalities and across census periods were associated with shifts in the potential drivers.

\section{What factors drive forest gains and losses over the study period?}

\section{Effects of biophysical factors}

Biophysical features of the municipalities were important determinants of forest cover change between 1960 and 2006 in São Paulo. Regeneration was concentrated in lands with low suitability for agriculture and/or agriculture mechanization, consistent with studies in Puerto Rico (Crk et al. 2009, Yackulic et al. 2011) and in São Paulo (Silva et al. 2007, 2016, Teixeira et al. 2009, Molin et al. 2017). On the other hand, soil water retention capacity, an important indicator of agricultural suitability, was associated with forest loss in 1960-1996 but not in 1996-2006. These patterns are probably related to the agricultural intensification, which made low productivity, steep lands less attractive for landowners leading to land abandonment and regeneration, as predicted by the FTT (Mather and Needle 1998). Nevertheless, the creation of the National Council of Environment (CONAMA) and Brazilian Institute of Environment and Natural Resources (IBAMA) by the Brazilian Government, and the São Paulo State Council of Environment (CONSEMA) during the 1980s may have also played a role on sparing fragile areas, e.g., steep slopes and riparian zones, fostering regeneration from 1980 onward, and also hindering further deforestation of suitable lands in 1996-2006.

Our results also indicate that the extent of forest cover facilitated forest gains in São Paulo in 1960-2006, besides most of the municipalities presented very low percentage of forest cover in private properties $(<30 \%$; Fig. A1.1). Forest regrowth may have been facilitated by the presence of nearby forest remnants because they are important seed sources after land-use abandonment (Baider et al. 2001) and shelter important seed dispersers (Holl 1999, Hooper et al. 2004, Babweteera and Brown 2009). Nevertheless, the substitution of old-growth by second-growth forests is possibly contributing to the impoverishment of the forests and the decline in the provision of ecosystem services in the state (Ferraz et al. 2014). Hence, the forest net gains in São Paulo may not bring large benefits for biodiversity conservation without preservation of primary forests or restoration efforts on private lands.

\section{Effects of land-use change}

Pasture expansion occurred mainly in western and northwestern municipalities (Fig. A1.5) and was related to deforestation in 1960-1970 and 1980-1996 (Fig. 4). In 1960-1970 deforestation was probably related to the substitution of coffee and cotton plantations in western and northwestern São Paulo by extensive pasture, which was a cheap alternative to cope with the coffee and cotton crises of the 1960s (Bini 2009), and possibly promoted further forest loss. In 1970-1980 and 1980-1996, pasture continued to expand in those regions (Fig. A1.5) where land prices were relatively low (Bini 2009), possibly as a consequence of pasture displacement from other regions by more lucrative crops such as sugarcane, orange, and soybean (Camargo and Santos 1985, Sparovek et al. 2007). Our analyses show that there was interdependence between some of São Paulo's regions in which crop substitution in one region occurs at the expense of agricultural expansion on more suitable or cheaper lands in others, a process observed at the intra-national scale elsewhere (Pfaff and Walker 2010). However, how land-use change in one São Paulo region has been affecting forest cover change in others is not well understood and should be explored in future studies.

Increases in annual crops occurred throughout the state (Fig. A1.7) but were associated with deforestation only in 1960-1970 (Fig. 4, Table 2). From 1970 onward increases in annual crops probably occurred at the expense of other crops. High sugar prices during 1960s encouraged sugarcane expansion in the state (Silva 1983), while research and innovation facilitate soybean expansion in the Cerrado (Camargo and Santos 1985). As a result, sugarcane and soybean production for export increased substantially (Carvalho and Silva 1987), potentially leading to significant deforestation. On the other hand, the expansion of annual crops from the 1970s onward (Fig. A1.7) is possibly related to sugarcane expansion, the main annual crop in São Paulo, which was encouraged by the creation of the PROÁLCOOL in 1973 (Fig. 2). However, this expansion has occurred primarily at the expense of pasture in São Paulo (Adami et al. 2012, Ferreira et al. 2015), explaining the lack of association between annual crop expansion and deforestation in the state from 1970 onward (Fig. 4, Table 2). However, other environmental concerns have risen from the accelerated sugarcane expansion in São Paulo such as higher pesticide and chemical fertilizer use, and the displacement of extensive cattle ranches to other Brazilian regions, mainly centralwest Cerrados and Amazon, that may have contributed to deforestation in those regions (Sparovek et al. 2007, Adami et al. 2012).

Expansion of perennial crops was associated with forest loss in 1960-1970 and 1980-1996, possibly reflecting the effects of citrus expansion during the 1960s and 1980s. In the 1960s, São Paulo shifted from exporting raw oranges to concentrated juice, a shift that may have promoted crop expansion (Maia 1996). By the 1980 s, the state became the main producer and exporter of concentrated juice in the world, encouraging further expansion of citrus cultivation (Amaro 1996, Maia 1996) which possibly occurred in part at the expense of native forest cover. These patterns of land use and forest cover change highlight the vulnerability of native areas in the tropics to the variation of crop prices in the international market as also observed by studies in Brazil and other tropical countries (Morton et al. 2006, Hosonuma et al. 2012, Karstensen et al. 2013).

Exotic tree expansion was associated with deforestation in 1980 1996 and forest gains in 1996-2006, indicating that different underlying factors influenced exotic tree plantation expansion and, consequently, forest cover change in São Paulo between 1980 and 2006. The expansion of exotic tree plantation in 1980-1996 may reflect economic incentives granted by the Brazilian Government to forestry industries and landowners between 1966 and 1987 (Viana 2004). However, the optimization of the productive chain of pulp and paper and the demand for environmental certification of plantations may have promoted further land abandonment to increase native forest cover (Farinaci et al. 2013, Silva et al. 2016). Hence, our results show that the same proximate driver can have opposite effects on forest cover change depending on the underlying ultimate driver, 
highlighting the importance of long-term studies that capture different economic and political contexts.

As we expected, increases in uncultivated lands were related to forest gains, but only in 1996-2006, although the percentage of uncultivated land decreased in most municipalities through time (Fig. A1.9, Table A1.1). Probably, the increase in fertilizer use after 1960 encouraged the decline of the uncultivated land in the state while land-use intensification encouraged further land abandonment and forest increase in 1996-2006. However, it may also reflect compliance with the Brazilian Forest Code (BFC) and state environmental regulations in order to obtain environmental certification and reach foreign markets, a process that has fostered land abandonment for reforestation, as observed by other studies in São Paulo (Farinaci et al. 2013, Silva et al. 2016). Our results indicate that land abandonment, mainly of less suitable lands for agriculture, has been an important source of forest gains in São Paulo's municipalities, as also observed by other studies at a smaller scale in São Paulo state (Silva et al. 2016, Molin et al. 2017), although our aggregate data do not allow us to assess exactly where and in what circumstances those lands were abandoned.

\section{Effects of farm productivity}

Agriculture intensification and higher productivity, expressed by the increased fertilizer use in agriculture, apparently enabled the abandonment of marginal lands and forest gains in 1996-2006, as discussed above. Both factors, use of fertilizer and percent of uncultivated lands, created a positive effect on forest cover in 1996-2006 (Fig.4), while the use of fertilizer increased (Fig. A1.3, Table A1.1) and the percent of uncultivated land decreased in most municipalities through time (Fig.A1.9, Table A1.1). It seems that the increase of agricultural inputs encouraged the expansion of crops over uncultivated lands after 1960, but shifts in land use and agriculture intensification probably encouraged further abandonment of less fertile and/or more declivitous lands, leading to the forest cover increase. These results corroborate our main hypothesis that factors that increase land productivity and decrease the pressure on land development can drive forest cover increase, as suggested by FTT (Mather and Needle 1998).

\section{CONCLUSION}

São Paulo exhibited marked changes in forest cover between 1960 and 2006, with forest loss occurring between 1960 and 1980 and the transition to reforestation from 1980 onward. Deforestation occurred mainly in municipalities in the western and north regions of São Paulo between 1960 and 1980, while regeneration occurred in most municipalities between 1980 and 2006. Nevertheless, different proximate factors were related to forest cover gains and losses between 1960 and 2006. In 1960-1970, the expansion of perennial crops, annual crops, and pasture were related to deforestation in São Paulo, while no particular land use tested was associated to deforestation in 1970-1980. Although forest gains occurred in most municipalities in 1980-1996, the deforestation during this period was related to the expansion of perennial crops, pasture, and exotic tree plantation in the municipalities. On the other hand, in 1996-2006, the expansion of exotic tree plantation and uncultivated land, and the use of fertilizers were associated with forest gains. During all periods, deforestation occurred mainly in municipalities with high soil water retention capacity and regeneration occurred mainly in municipalities with steeper slopes and high percentage of native forest cover, indicating that the less fertile and steep lands were more likely to be abandoned and the presence of nearby forest remnants possibly facilitated the forest regrowth.

The variation of the biophysical and socioeconomic factors that drove forest cover change over time and space in the state shows that human pressure on land shifts was responsive to economic changes and political measures, as also observed by other studies in São Paulo and in Brazil. Our results indicate that agricultural expansion encouraged deforestation on most suitable agricultural lands. More recently, a number of factors that increased productivity or reduced pressure on land development drove forest regeneration. Ultimately, however, these proximate factors were possibly driven by governmental policies to modernize agriculture, e.g., PROÁLCOOL and RCSS, to protect natural ecosystems, e.g., BFC, CONSEMA, CONAMA, and IBAMA, and by international market demands for environmental certification.

In this context, the state of São Paulo exemplifies the advanced stages of agriculture consolidation and intensification processes that have fostered forest cover increases over the past few decades. This context represents an outcome of exogenous socioeconomic factors affecting land use. Results suggest that state regulation and economic incentives played a relevant role in forest transition in the state of São Paulo. Additionally, up-to-date economic growth promoted by agro-industry in São Paulo has been decoupled from overall social development, a common pattern in tropical developing countries.

However, the aggregate patterns of our results do not clarify the variation in land-use change between decades and across municipalities of São Paulo, hindering our ability to identify patterns of land-use substitution over time and their effects on forest gains or losses in finer scales. Additionally, those aggregate patterns did not allow us to infer about the decline of primary forest that occurred in parallel with the increase of the secondary forest, a process observed by other studies in finer scales. Future studies using spatially explicit approaches at finer scales should account for the effects of land-use substitution on forest cover change, and also account for the effects of the land-use change on the substitution of primary by secondary forests in São Paulo.

Responses to this article can be read online at: http://www.ecologyandsociety.org/issues/responses. php/10270

\footnotetext{
Acknowledgments:

Adriane Calaboni was funded by the Brazilian Ministry of Education (CAPES) doctoral studentship. We would like to thank Dr. Jefferson Mariano (IBGE/SP) and Antônio Carlos Simões Florido (IBGE/RJ) for gently helping authors with SIDRA database and Brazilian National Agrarian Census Survey data. We also thank MSc. Julia Barreto, Dr. Mariana Morais Vidal, Dr. Paula Ribeiro Prist, Dr. Cristina Banks-Leite, and Dr. Elizabeth Nichols for the insights that greatly improved the manuscript.
} 


\section{LITERATURE CITED}

Adami, M., B. F. T. Rudorff, R. M. Freitas, D. A. Aguiar, L. M. Sugawara, and M. P. Mello. 2012. Remote sensing time series to evaluate direct land use change of recent expanded sugarcane crop in Brazil. Sustainability 4:574-585. http://dx.doi. org/10.3390/su4040574

Aide, T. M., M. L. Clark, H. R. Grau, D. Lópes-Carr, M. A. Levy, D. Redo, M. Bonilla-Moheno, G. Riner, M. J. Andrade-Núñez, and M. Muñiz. 2013. Deforestation and reforestation of Latin America and the Caribbean (2001-2010). Biotropica 45:262-271. http://dx.doi.org/10.1111/j.1744-7429.2012.00908.x

Amaro, A. A. 1996. Situação e perspectivas da citricultura. Informações Econômicas 26:23-26. [online] URL: http://www.iea. sp.gov.br/out/verTexto.php?codTexto $=13893$

Babweteera, F., and N. Brawn. 2009. Can remnant frugivore species effectively disperse tree seeds in secondary tropical rain forests? Biodiversity and Conservation 18:1611-1627. http://dx. doi.org/10.1007/s10531-008-9546-6

Baer, W. 2008. The Brazilian growth and development. Sixth Edition. Lynne Rienner Publishers, Boulder, Colorado, USA.

Baider, C., M. Tabarelli, and W. Mantovani. 2001. The soil seed bank during Atlantic forest regeneration in southeast Brazil. Revista Brasileira de Biologia 61:35-44. http://dx.doi.org/10.1590/ $\underline{\text { S0034-71082001000100006 }}$

Baptista, S. R. 2008. Metropolization and forest recovery in southern Brazil: a multiscale analysis of the Florianópolis cityregion, Santa Catarina State, 1970 to 2005. Ecology and Society 13(2):5. http://dx.doi.org/10.5751/ES-02426-130205

Barretto, A. G. O. P., G. Berndes, G. Sparovek, and S. Wirsenius. 2013. Agricultural intensification in Brazil and its effects on landuse patterns: an analysis of the 1975-2006 period. Global Change Biology 19:1804-1815. http://dx.doi.org/10.1111/gcb.12174

Barton, K. 2016. MuMIn: Rpackage for model selection andmultimodel inference. [online] URL: http://mumin.r-forge.r-project. org/

Bini, D. L. de C. 2009. Mudanças na composição das culturas agrícolas e a urbanização na região de Araçatuba. Informações Econômicas 39:63-75.

Brancalion, P. H. S., D. Schweizer, U. Gaudare, J. R. Mangueira, F. Lamonato, F. T. Farah, A. G. Nave, and R. R. Rodrigues. 2016. Balancing economic costs and ecological outcomes of passive and active restoration in agricultural landscapes: the case of Brazil. Biotropica 48:856-867. http://dx.doi.org/10.1111/btp.12383

Burnham, K. P., and D. R. Anderson. 2002. Model selection and multimodel inference: a pratical information-theoretic approach. Second Edition. Springer-Verlag, New York, New York, USA. http://dx.doi.org/10.1007/b97636

Calaboni, A. 2017. Transição florestal no estado de São Paulo, Brasil: fatores associados ao desmatamento e recuperação das matas nativas. Dissertation. Universidade de São Paulo, Brasil. http://dx.doi.org/10.11606/T.41.2017.tde-18082017-170805

Camargo, A. M. M., and Z. A. P. Santos. 1985. Mudança na composição agrícola paulista: o caso da soja, da laranja e da cana- de-açúcar. Instituto de Economia Agrícola, São Paulo, Brasil. [online] URL: http://www.iea.sp.gov.br/out/TerTexto.php? $\underline{\text { codTexto }=10619}$

Carvalho, M. A., and C. R. L. Silva. 1987. Uma análise dos fatores que influenciaram a produção agrícola no Estado de São Paulo: alimentos vs. produtos exportáveis. Instituto de Economia Agrícola, São Paulo, Brasil. [online] URL: http://www.iea.sp.gov. br/out/TerTexto.php?codTexto $=10661$

Chabaribery, D. 1999. Inovação e desigualdade no desenvolvimento da agricultura paulista. Coleção de Estudos Agrícolas 7:1-178. [online] URL: http://www.iea.sp.gov.br/out/ verTexto.php?codTexto $=9623$

Chazdon, R. L., and M. R. Guariguata. 2016. Natural regeneration as a tool for large-scale forest restoration in the tropics: prospects and challenges. Biotropica 48:716-730. http:// dx.doi.org/10.1111/btp.12381

Chowdhury, R. R. 2007. Household land management and biodiversity: secondary succession in a forest-agriculture mosaic in southern Mexico. Ecology and Society 12(2):31. http://dx.doi. org/10.5751/ES-02189-120231

Crk, T., M. Uriarte, F. Corsi, and D. Flynn. 2009. Forest recovery in a tropical landscape: What is the relative importance of biophysical, socioeconomic, and landscape variables? Landscape Ecology 24:629-642. http://dx.doi.org/10.1007/s10980-009-9338-8

Costa, R. L., J. A. Prevedello, B. G. de Souza, and D. C. Cabral. 2017. Forest transition in tropical landscape: a test in the Atlantic Forest biodiversity hotspot. Applied Geography 82:93-100. http:// dx.doi.org/10.1016/j.apgeog.2017.03.006

DeFries, R. S., T. K. Rudel, M. Uriarte, and M. Hansen. 2010. Deforestation driven by urban population growth and agricultural trade in the twenty-first century. Nature Geoscience 3:178-181. http://dx.doi.org/10.1038/ngeo756

Farinaci, J. S. 2012. As novas matas do estado de São Paulo: um estudo multiescalar sob a perspectiva da Teoria da Transição Florestal. Dissertation. Universidade Estadual de Campinas, São Paulo, Brasil.

Farinaci, J. S., and M. Batistella. 2012. Variação na cobertura vegetal nativa em São Paulo: um panorama do conhecimento atual. Revista Árvore 36:695-705. http://dx.doi.org/10.1590/ $\underline{\mathrm{S} 0100-67622012000400011}$

Farinaci, J. S., L. C. Ferreira, and M. Batistella. 2013. Transição florestal e modernização ecológica: a eucaliptocultura para além do bem e do mal. Ambiente e Sociedade 16:25-46. http://dx.doi. org/10.1590/S1414-753X2013000200003

Ferraz, S. F. B., K. M. P. M. B. Ferraz, C. C. Cassiano, P. H. S. Brancalion, D. T. A. da Luz, T. N. Azevedo, L. R. Tambosi, and J. P. Metzger. 2014. How good are tropical forest patches for ecosystem services provisioning? Landscape Ecology 29:187:200.

Ferreira, C. R. R. P. T., F. C. Carvalho, and A. J. B. Carmo. 1986. Evolução do setor de defensivos agrícolas no Brasil, 1964-83. Instituto de Economia Agrícola, São Paulo, Brasil. [online] URL: http://www.iea.sp.gov.br/out/TerTexto.php?codTexto $=10625$

Ferreira, M. P., D. S. Alves, and Y. E. Shimabukuro. 2015. Forest dynamics and land-use transitions in the Brazilian Atlantic 
Forest: the case of sugarcane expansion. Regional Environmental Change 15:365-377. http://dx.doi.org/10.1007/s10113-014-0652-6

Foley, J. A., R. DeFries, G. P. Asner, C. Barford, G. Bonan, S. R. Carpenter, F. S. Chapin, M. T. Coe, G. C. Daily, H. K. Gibbs, J. H. Helkowski, T. Holloway, E. A. Howard, C. J. Kucharik, C. Monfreda, J. A. Patz, I. C. Prentice, N. Ramankutty, and P. K. Snyder. 2005. Global consequences of land use. Science 309:570-574. http://dx.doi.org/10.1126/science.1111772

Freitas, S. R., T. J. Hawbaker, and J. P. Metzger. 2010. Effects of roads, topography, and land use on forest cover dynamics in the Brazilian Atlantic Forest. Forest Ecology and Management 259:410-417. http://dx.doi.org/10.1016/j.foreco.2009.10.036

Freitas, S. R., C. O. M. Sousa, D. Boscolo, and J. P. Metzger. 2013. How are native vegetation and reserves affected by different road types in a southeastern Brazilian state? Oecologia Australis 17:447-458. http://dx.doi.org/10.4257/oeco.2013.1704.01

Garcia, A. E. B. 1986. Ocupação da mão-de-obra na agricultura do Estado de São Paulo na década de setenta. Instituto de Economia Agrícola, São Paulo, Brasil. [online] URL: http://www. iea.sp.gov.br/out/LerTexto.php?codTexto $=10624$

Geist, H. J., and E. F. Lambin. 2002. Proximate causes and underlying driving forces of tropical deforestation. Bioscience 52:143-150. http://dx.doi.org/10.1641/0006-3568(2002)052[0143: PCAUDF]2.0.CO;2

Gelman, A., and J. Hill. 2006. Data analysis using regression and multilevel/hierarchical model. First Edition. Cambridge University Press, Cambridge, UK. http://dx.doi.org/10.1017/ $\underline{\text { CBO9780511790942 }}$

Ghilard, A. A. 1986. Transformações na agricultura paulista na década de setenta, ao nível de tamanho de propriedade. Instituto de Economia Agrícola, São Paulo, Brasil. [online] URL: http://www. iea.sp.gov.br/out/TerTexto.php?codTexto $=10677$

Gibbs, H. K., A. S. Ruesc, F. Achard, M. K. Clayton, P. Holmgren, N. Ramankutty, and J. A. Foley. 2010. Tropical forests were the primary sources of new agricultural land in 1980s and 1990s. Proceedings of the National Academy of Sciences of the United States 107(38):16732-16737. http://dx.doi.org/10.1073/pnas.0910275107

Grau, H. R., and M. Aide. 2008. Globalization and land-use transitions in Latin America. Ecology and Society 13(2):16. http:// dx.doi.org/10.5751/ES-02559-130216

Holl, K. D. 1999. Factors limiting tropical rain forest regeneration in abandoned pasture: seed rain, seed germination, microclimate, and soil. Biotropica 31:229-242. http://dx.doi.org/10.1111/ j.1744-7429.1999.tb00135.x

Hooper, E. R., P. Legendre, and R. Condit. 2004. Factors affecting community composition of forest regeneration in deforested, abandoned land in Panama. Ecology 85:3313-3326. http://dx.doi. org/10.1890/03-0655

Hosonuma, N., M. Herold, V. De Sy, R. S. DeFries, M. Brockhaus, L. Verchot, A. Angelsen, and E. Romijn. 2012. An assessment of deforestation and forest degradation drivers in developing countries. Environmental Research Letters 7:044009. http://dx. doi.org/10.1088/1748-9326/7/4/044009
IBGE (Brazilian Institute of Geography and Statistics). 2011. Características da população e dos domicílios: resultados do universo. IBGE, Rio de Janeiro, Brasil. [online] URL: https://ww2. ibge.gov.br/home/estatistica/populacao/censo2010/ default resultados universo.shtm

Karstensen, J., G. P. Peters, and R. B. Andrew. 2013. Attribution of $\mathrm{CO}_{2}$ emissions from Brazilian deforestation to consumers between 1990 and 2010. Environmental Research Letters 8:024005. http://dx.doi.org/10.1088/1748-9326/8/2/024005

Kronka, F. J. N., M. A. Nalon, C. K. Matsukuma, M. M. Kanashiro, M. S. Shin-Ike, M. Pavão, G. Durigan, L. M. P. R. Lima, J. R. Guillaumon, J. B. Baitello, et al. 2005. Inventário Florestal da Vegetação Natural do Estado de São Paulo. Instituto Florestal, São Paulo, Brasil. [online] URL: http://iflorestal.sp. gov.br/2005/03/01/inventario-florestal-da-vegetacao-natural-do-estadode-sao-paulo/

Lambin, E. F., and P. Meyfroidt. 2010. Land use transitions: socio-ecological feedback versus socio-economic change. Land Use Policy 27:108-118. http://dx.doi.org/10.1016/j.landusepol.2009.09.003

Lambin, E. F., and P. Meyfroidt. 2011. Global land use change, economic globalization, and the looming land scarcity. Proceedings of the National Academy of Sciences of the United States 108:3465-3472. http://dx.doi.org/10.1073/pnas.1100480108

Lapola, D. M., L. A. Martinelli, C. A. Peres, J. P. H. B. Ometto, M. E. Ferreira, Carlos A. Nobre, A. P. D. Aguiar, M. M. C. Bustamante, M. F. Cardoso, M. H. Costa, et al. 2014. Pervasive transition of the Brazilian land-use system. Nature Climate Change 4:27-35. http://dx.doi.org/10.1038/nclimate2056

Lira, P. K., L. R. Tambosi, R. M. Ewers, and J. P. Metzger. 2012. Land-use and land-cover change in Atlantic Forest landscapes. Forest Ecology and Management 278:80-89. http://dx.doi. org/10.1016/j.foreco.2012.05.008

Maia, M. L. 1996. Citricultura paulista: evolução, estrutura e acordo de preços. Instituto de Economia Agrícola, São Paulo, Brasil. [online] URL: http://www.iea.sp.gov.br/out/verTexto.php? $\underline{\text { codTexto }=10765}$

Martinelli, L. A. S., and S. Filoso. 2009. Balance between food production, biodiversity and ecosystem services in Brazil: a challenge and opportunity. Biota Neotropica 9:21-25. http://dx. doi.org/10.1590/S1676-06032009000400001

Martins, S. S. 1986. Agricultura paulista: da modernização à crise. Instituto de Economia Agrícola, São Paulo, Brasil. [online] URL: http://www.iea.sp.gov.br/out/verTexto.php?codTexto=10629

Mather, A. S., and C. L. Needle. 1998. The forest transition: a theoretical basis. Area 30:117-124. http://dx.doi.org/10.1111/ j.1475-4762.1998.tb00055.x

Meyfroidt, P., K. M. Carlson, M. E. Fagan, V. H. Gutiérrez-Vélez, M. N. Macedo, L. M. Curran, R. S. DeFries, G. A. Dyer, H. K. Gibbs, E. F. Lambin, D. C. morton, and V. Robiglio. 2014. Multiple pathways of commodity crop expansion in tropical forest landscapes. Environmental Research Letters 9:074012. http://dx.doi.org/10.1088/1748-9326/9/7/074012

Molin, P. G., S. E. Gergel, B. S. Soares-Filho, and S. F. B. Ferraz. 2017. Spatial determinants of Atlantic Forest loss and recovery 
in Brazil. Landscape Ecology 32:857-870. http://dx.doi. org/10.1007/s10980-017-0490-2

Morton, D. C., R. S. DeFries, Y. E. Shimabukuro, L. O. Anderson, E. Arai, F. del Bon Espirito-Santo, R. Freitas, and J. Morisette. 2006. Cropland expansion changes deforestation dynamics in the southern Brazilian Amazon. Proceedings of the National Academy of Sciences of the United States of America 103:14637-14641 http://dx.doi.org/10.1073/pnas.0606377103

Navarro, Z. 2010. A half-century of transformations in the Brazilian rural scenario and the governmental action. Revista de Política Agrícola 19:105-110.

Oliveira, J. B., M. N. Camargo, M. Rossi, and B. Calderano Filho. 1999. Mapa Pedológico do Estado de São Paulo: Legenda Expandida. Embrapa-Solos/IAC, Campinas, Brasil.

Parés-Ramos, I. K., W. A. Gould, and T. M. Aide. 2008. Agricultural abandonment, suburban growth, and forest expansion in Puerto Rico between 1991 and 2000. Ecology and Society 13(2):1. http://dx.doi.org/10.5751/ES-02479-130201

Perz, S. G. 2007. Grand theory and context-specificity in the study of forest dynamics: forest transition theory and other directions. Professional Geographer 59:105-114. http://dx.doi.org/10.1111/ j.1467-9272.2007.00594.X

Pfaff, A., and R. Walker. 2010. Regional interdependence and forest "transitions": substitute deforestation limits the relevance of local reversals. Land Use Policy 27:119-129. http://dx.doi. org/10.1016/j.landusepol.2009.07.010

Pino, F. A. 2016. Tamanho das culturas agrícolas no estado de São Paulo no início do século XXI. Informações Econômicas 46:34-52. [online] URL: http://www.iea.sp.gov.br/out/LerTexto. php?codTexto $=14136$

R Development Core Team. 2016a. The R Stats Package. Vienna, Austria. [online] URL: https://stat.ethz.ch/R-manual/R-devel/ library/stats/html/00Index.html.

R Development Core Team. 2016b. R: A language and environment for statistical computing. Vienna, Austria. [online] URL: https:// www.r-project.org/

Redo, D. J., H. R. Grau, T. M. Aide, and M. L. Clark. 2012. Asymmetric forest transition driven by the interaction of socioeconomic development and environmental heterogeneity in Central America. Proceedings of the National Academy of Sciences of the United States 109:8839-8844. http://dx.doi. org/10.1073/pnas. 1201664109

Rezende, C. L., A. Uezu, F. R. Scarano, and D. S. D. Araujo. 2015. Atlantic forest spontaneous regeneration at landscape scale. Biodiversity Conservation 24:2255-2272. http://dx.doi.org/10.1007/ $\underline{\text { s10531-015-0980-y }}$

Ribeiro, M. C., J. P. Metzger, A. C. Martensen, F. J. Ponzoni, and M. M. Hirota. 2009. The Brazilian Atlantic Forest: How much is left, and how is the remaining forest distributed? Implications for conservation. Biological Conservation 142:1141-1153. http://dx. doi.org/10.1016/i.biocon.2009.02.021

Rietbergen-McCracken, J., S. Maginnis, and A. Sarre. 2007. The forest landscape restoration handbook. Earthscan, London, UK.
Rudel, T. K. 2015. Have tropical deforestation's changing dynamics created conservation opportunities? A historical analysis. Environmental Conservation 42:108:118. http://dx.doi. org/10.1017/S0376892914000228

Rudel, T. K., O. T. Coomes, E. Moran, F. Achard, A. Angelsen, J. Xu, and E. F. Lambin. 2005. Forest transitions: towards a global understanding of land use change. Global Environmental Change 15:23-31. http://dx.doi.org/10.1016/j.gloenvcha.2004.11.001

Silva, C. R. L. 1983. A crise energética e o PROÁLCOOL: algumas configurações. Instituto de Economia Agrícola, São Paulo, Brasil. [online] URL: http://www.iea.sp.gov.br/ftpiea/RP/1983/relat-1183. pdf

Silva, R. F. B., M. Batistella, and E. F. Moran. 2016. Drivers of land change: human-environment interactions and the Atlantic forest transition in the Paraíba Valley, Brazil. Land Use Policy 58:133-144. http://dx.doi.org/10.1016/j.landusepol.2016.07.021

Silva, W. G., J. P. Metzger, S. Simões, and C. Simonetti. 2007. Relief influence on the spatial distribution of the Atlantic Forest cover on the Ibiúna Plateau, SP. Brazilian Journal of Biology 67:403-411. http://dx.doi.org/10.1590/S1519-69842007000300004

SOS/INPE (SOS Mata Atlântica and National Institute for Space Research). 2015. Atlas dos Remanescentes Florestais da Mata Atlântica: Relatório Técnico 2013-2014. São Paulo, Brasil. [online] URL: http://mapas.sosma.org.br/dados/\#

Sparovek, G., G. Berndes, A. Egeskog, F. L. M. Freitas, S. Gustafsson, and J. Hansson. 2007. Sugarcane ethanol production in Brazil: an expansion model sensitive to socioeconomic and environmental concerns. Biofuels, Bioproducts and Biorefining 1:270-282. http://dx.doi.org/10.1002/bbb.31

Teixeira, A. M. G., B. S. Soares-Filho, S. R. Freitas, and J. P. Metzger. 2009. Modeling landscape dynamics in an Atlantic Rainforest region: implications for conservation. Forest Ecology and Management 257:1219-1230. http://dx.doi.org/10.1016/j. foreco.2008.10.011

Thomlinson, J. R., M. I. Serrano, T. D. Lopez, T. M. Aide, and J. K. Zimmerman. 1996. Land-use dynamics in a post-agricultural Puerto Rican landscape (1936-1988). Biotropica 28:525-536. http://dx.doi.org/10.2307/2389094

Veiga, J. E. R., and M. N. Otani. 1983. Relações de trabalho na agricultura paulista: o declínio da mão-de-obra permanente. Instituto de Economia Agrícola, São Paulo, Brasil. [online] URL: http://www.iea.sp.gov.br/out/LerTexto.php?codTexto=12011.

Viana, M. B. 2004. O eucalipto e os efeitos ambientais do seu plantio em escala. Câmara dos Deputados, Brasília, Brasil.

Vicente, M. C. M., C. S. L. Baptistella, S. M. Freitas, and E. Madeira. 1988. População residente nos imóveis rurais do Estado de São Paulo: alguns indicadores sócio-econômicos, 1970-86. Instituto de Economia Agrícola, São Paulo, Brasil. [online] URL: http://www.iea.sp.gov.br/out/LerTexto.php?codTexto=10711

Yackulic, C. B., M. Fagan, M. Jain, Y. Lim, M. Marlier, R. Muscarella, P. Adame, R. DeFries, and M. Uriarte. 2011. Biophysical and socioeconomic factors associated with forest transitions at multiple spatial and temporal scales. Ecology and Society 16(3):15. http://dx.doi.org/10.5751/ES-04275-160315 
Appendix 1. Temporal changes (Table A1.1) and geographical distribution of the socioeconomic and biophysical factors (Fig. A1.1A1.10) of all municipalities of São Paulo State between 1960 and 2006.

We applied a Kruskal-Wallis test for assessing the potential differences between years (1960, 1970, 1980, 1996 and 2006) of each explanatory variable. The Kruskal-Wallis test was chosen because the data were not normally distributed neither presented homogeneity of variances. All analyses were conducted using R statistical software (R Development Core Team 2016).

Table A1.1 Median of each explanatory variable for the years 1960, 1970, 1980, 1996 and 2006, and the Kruskal-Wallis results comparing those years. The distinct superscript letters indicate for which years the difference between the medians is statistically significant.

\begin{tabular}{lcccccccc}
\hline \multicolumn{1}{c}{ Explanatory variables } & \multicolumn{3}{c}{ Median } & \multicolumn{3}{c}{ Kruskal-Wallis test } \\
\cline { 2 - 8 } & 1960 & 1970 & 1980 & 1996 & 2006 & df & $\chi^{2}$ & $P$-value \\
\hline Annual crops (\%) & $13.45^{\mathrm{a}}$ & $15.77^{\mathrm{a}, \mathrm{b}}$ & $14.29^{\mathrm{a}}$ & $14.13^{\mathrm{a}}$ & $19.13^{\mathrm{b}}$ & 4 & 14.65 & $0.0054^{*}$ \\
Perennial crops (\%) & $7.56^{\mathrm{a}}$ & $4.77^{\mathrm{b}}$ & $6.67^{\mathrm{a}}$ & $4.01^{\mathrm{b}}$ & $6.98^{\mathrm{a}}$ & 4 & 67.63 & $<0.0001^{*}$ \\
Forest cover (\%) & $8.24^{\mathrm{a}}$ & $5.61^{\mathrm{b}}$ & $4.36^{\mathrm{c}}$ & $5.01^{\mathrm{b}}$ & $8.29^{\mathrm{a}}$ & 4 & 213.16 & $<0.0001^{*}$ \\
Pasture (\%) & $50^{\mathrm{a}}$ & $56.55^{\mathrm{b}}$ & $51.60^{\mathrm{a}, \mathrm{c}}$ & $53.64^{\mathrm{b}, \mathrm{c}}$ & $44.76^{\mathrm{d}}$ & 4 & 45.87 & $<0.0001^{*}$ \\
Exotic tree plantation (\%) & $1.35^{\mathrm{a}}$ & $1.03^{\mathrm{a}, \mathrm{b}}$ & $1.01^{\mathrm{a}}$ & $0.68^{\mathrm{b}}$ & $0.27^{\mathrm{c}}$ & 4 & 138.25 & $<0.0001^{*}$ \\
Uncultivated land (\%) & $3.43^{\mathrm{a}}$ & $3.54^{\mathrm{a}}$ & $0.71^{\mathrm{b}}$ & $0.46^{\mathrm{c}}$ & $0.022^{\mathrm{d}}$ & 4 & 1374.5 & $<0.0001^{*}$ \\
Tractors per area (n tractor / ha) & $0.0012^{\mathrm{a}}$ & $0.0027^{\mathrm{b}}$ & $0.0064^{\mathrm{c}}$ & $0.0092^{\mathrm{d}}$ & $0.0087^{\mathrm{d}}$ & 4 & 1179.7 & $<0.0001^{*}$ \\
Density of farm workers (n of worker / ha) & $0.090^{\mathrm{a}}$ & $0.072^{\mathrm{b}}$ & $0.073^{\mathrm{b}}$ & $0.051^{\mathrm{c}}$ & $0.055^{\mathrm{c}}$ & 4 & 158.91 & $<0.0001^{*}$ \\
Farms that uses fertilizer (\% of farms) & $35.49^{\mathrm{a}}$ & $49.68^{\mathrm{b}}$ & $81.90^{\mathrm{c}}$ & $72.48^{\mathrm{d}}$ & - & 3 & 632.67 & $<0.0001^{*}$ \\
\hline
\end{tabular}

“*” indicates the statistical significance at the level $\alpha=0.05$ 

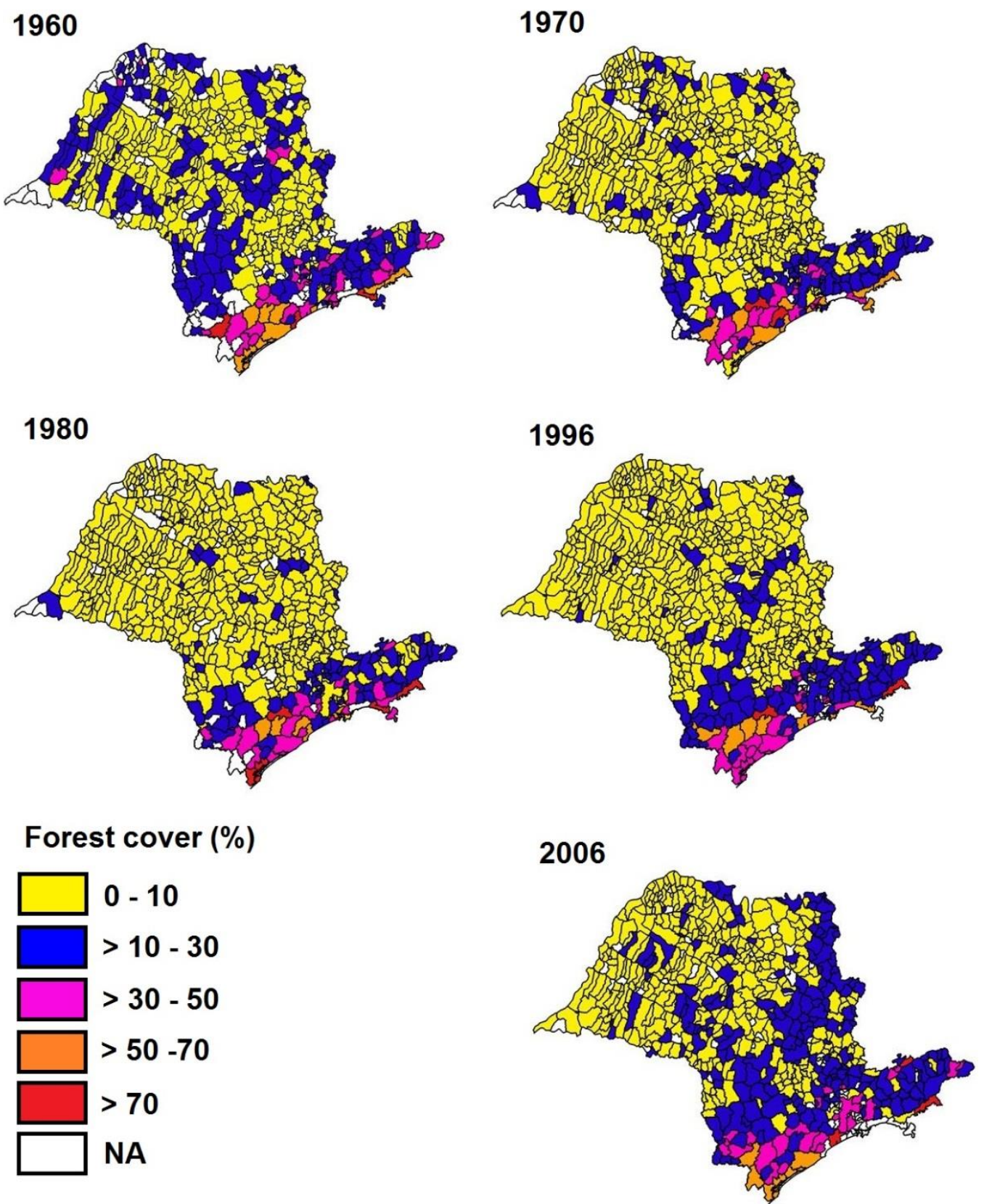

FIGURE A1.1 Percentage of forest cover at the municipality-scale for São Paulo state calculated for the years 1960, 1970, 1980, 1996 and 2006. Municipality boundaries are shown in black. (NA) Missing values. 

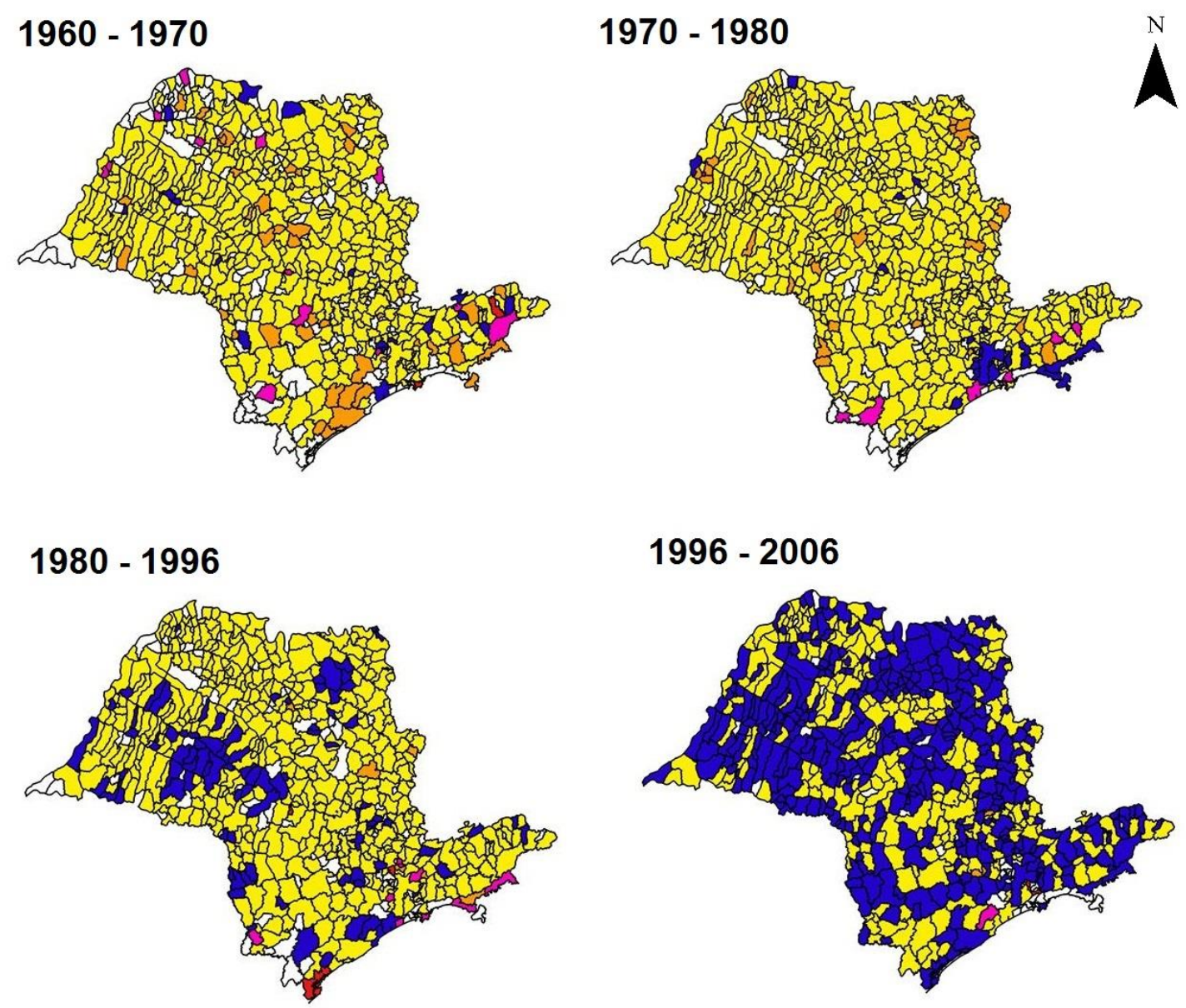

Tractors per area (ratio)
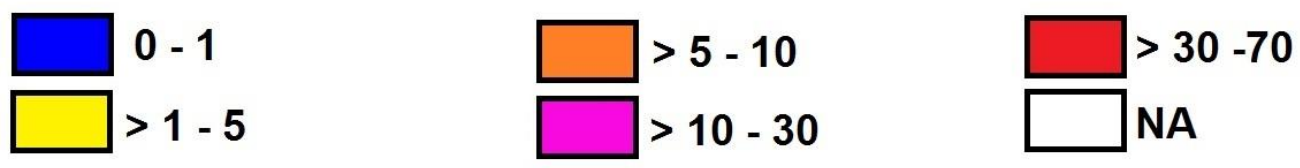

FIGURE A1.2 Tractors per area ratio at the municipality-scale for São Paulo state calculated for the intervals 1960-1970, 1970-1980, 1980-1996 and 1996-2006. The ratio of tractors per area was calculated by dividing the values of tractors per area of one census by the values of tractors per area of the previous census (e.g. values in 1970 / values in 1960). Ratio values greater than 1 (one) indicate that tractors per area increased over the census interval and values lower than 1 (one) indicate that it decreased. Municipality boundaries are shown in black. (NA) Missing values. 

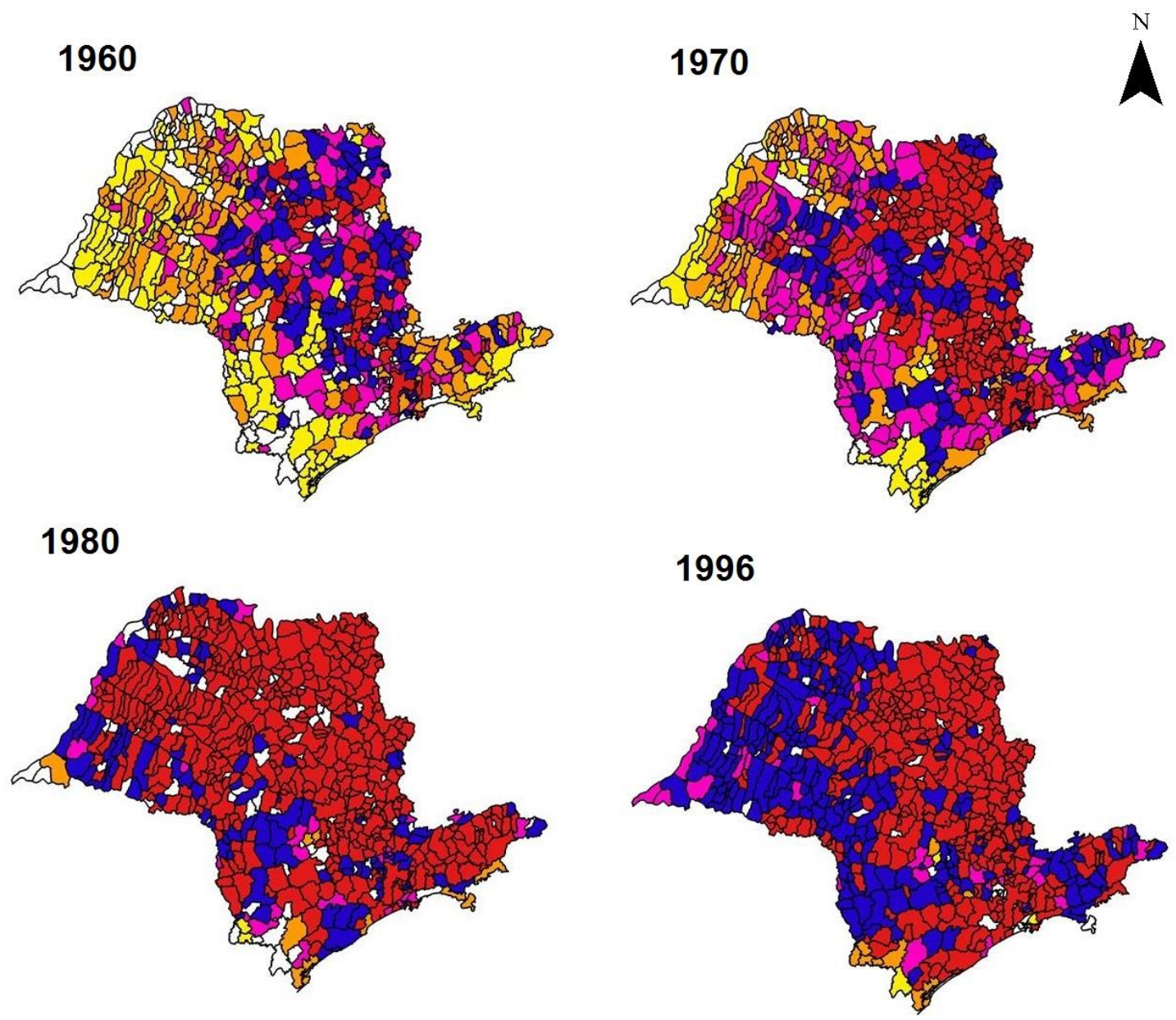

Establishments that used fertiliers (\%)
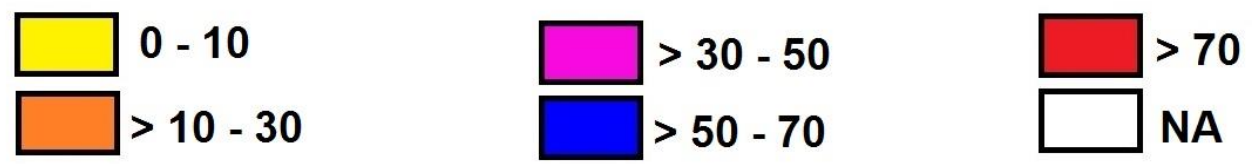

FIGURE A1.3 Percentage of establishments that used fertilizer at the municipality-scale for São Paulo state calculated for the years 1960, 1970, 1980 and 1996. Municipality boundaries are shown in black. (NA) Missing values. 

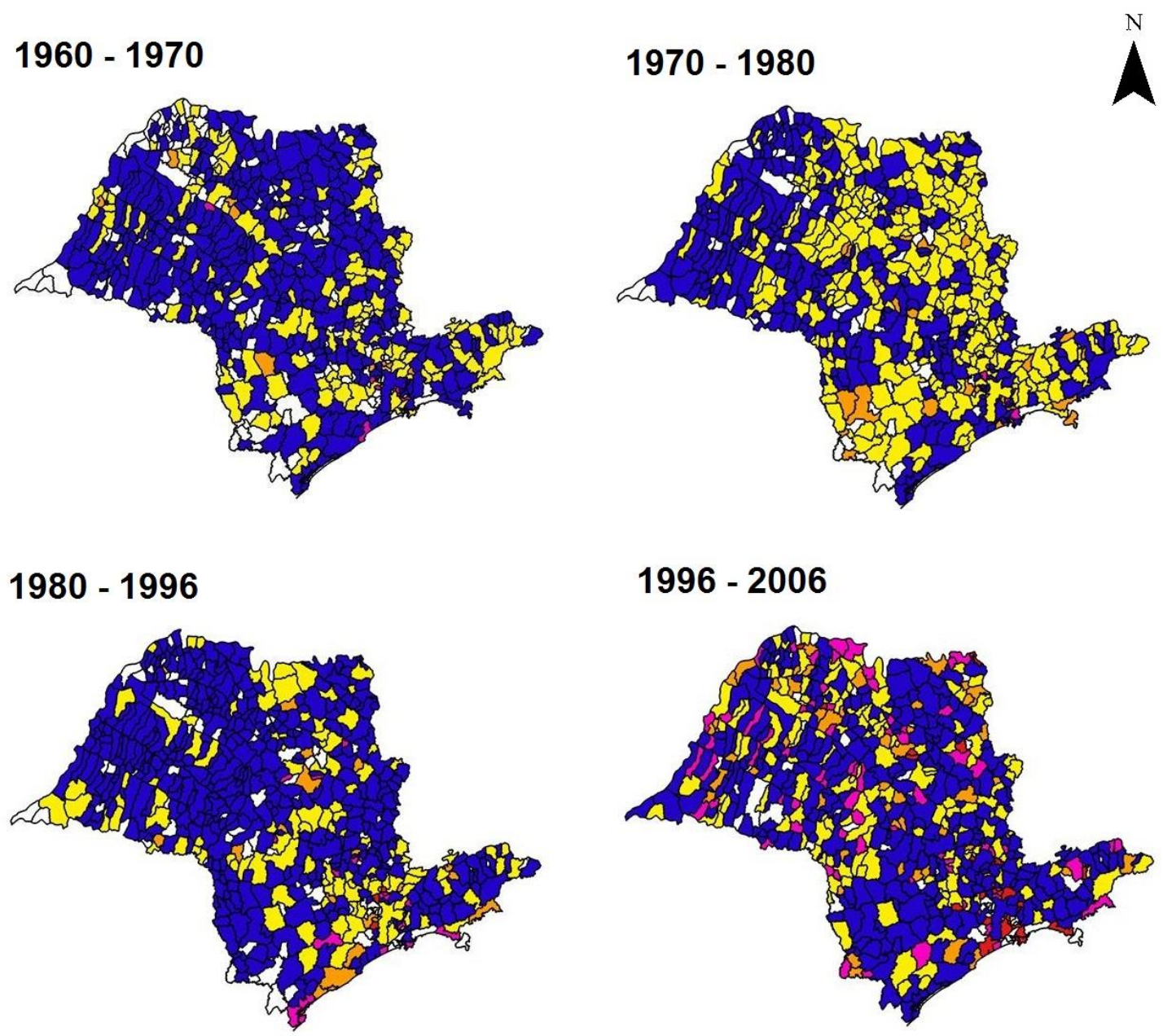

\section{Density of workers on farms (ratio)}
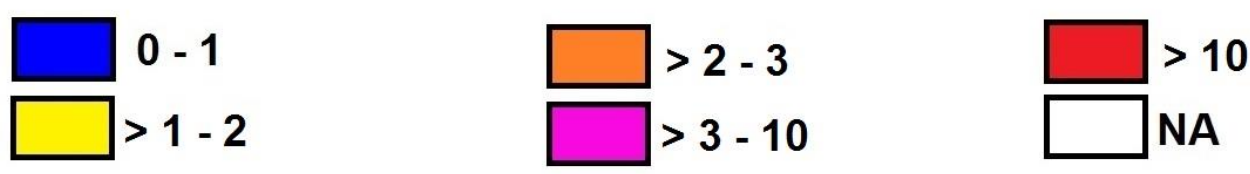

FIGURE A1.4 Density of workers on farms ratio at the municipality-scale for São Paulo state calculated for the intervals 1960-1970, 1970-1980, 1980-1996 and 1996-2006. Density of workers on farms ratio was calculated by dividing the density of workers in one census by the density of workers in the previous census (e.g. values in 1970 / values in 1960). Ratio values greater than 1 (one) indicate that density of workers increased over the census interval and values lower than 1 (one) indicate that it decreased. Municipality boundaries are shown in black. (NA) Missing values. 

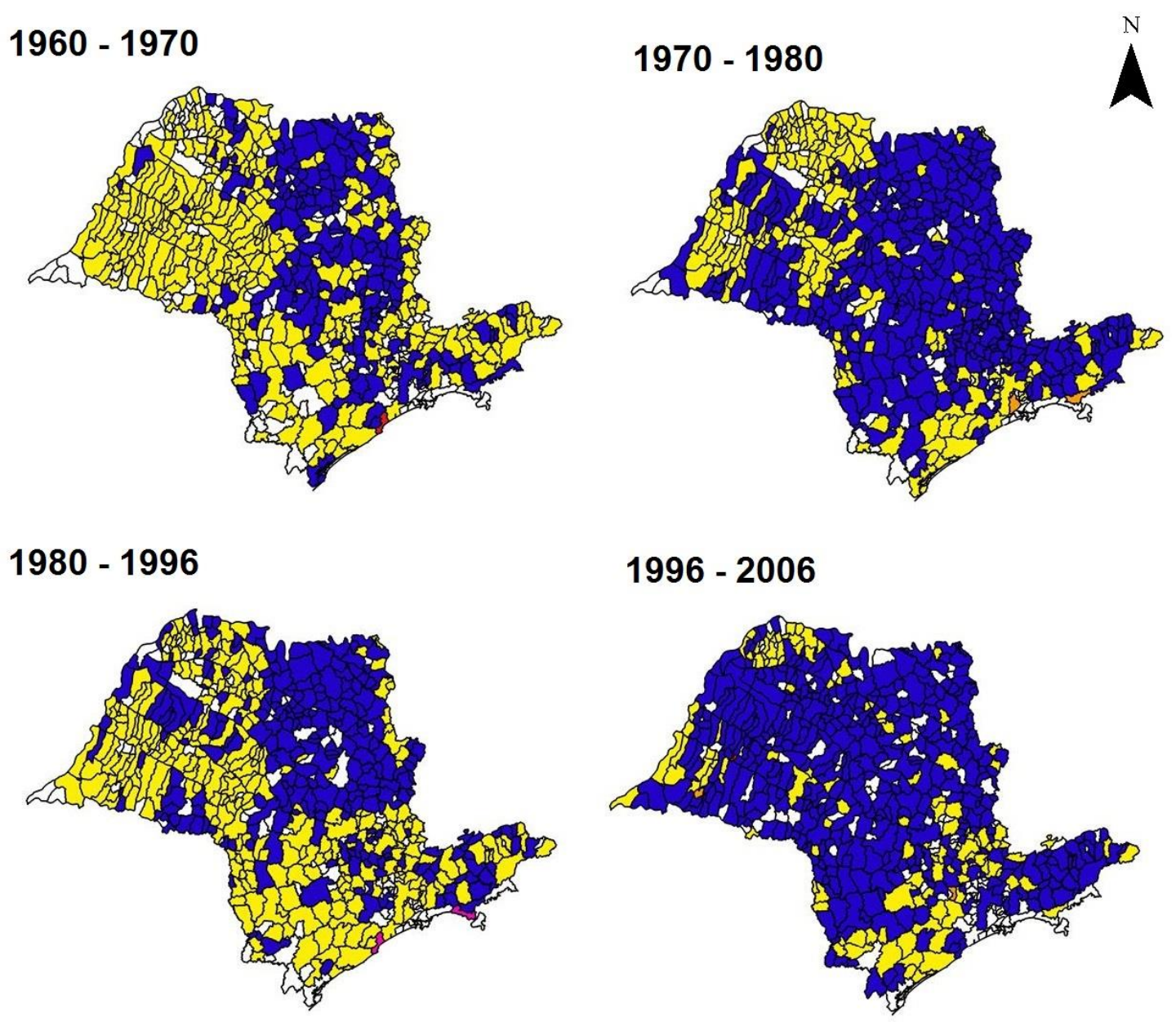

Pasture (ratio)
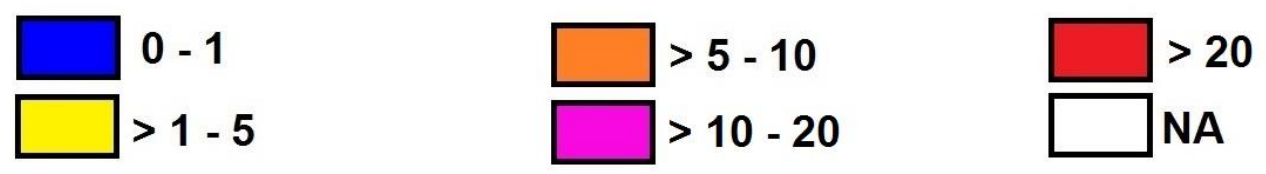

FIGURE A1.5 Pasture ratio at the municipality-scale for São Paulo state calculated for the intervals 1960-1970, 1970-1980, 1980-1996 and 1996-2006. Pasture ratio was calculated by dividing the pasture percentage in one census by pasture percentage in the previous census (e.g. values in 1970 / values in 1960). Ratio values greater than 1 (one) indicate that pasture increased over the census interval and values lower than 1 (one) indicate that it decreased. Municipality boundaries are shown in black. (NA) Missing values. 
$1960-1970$
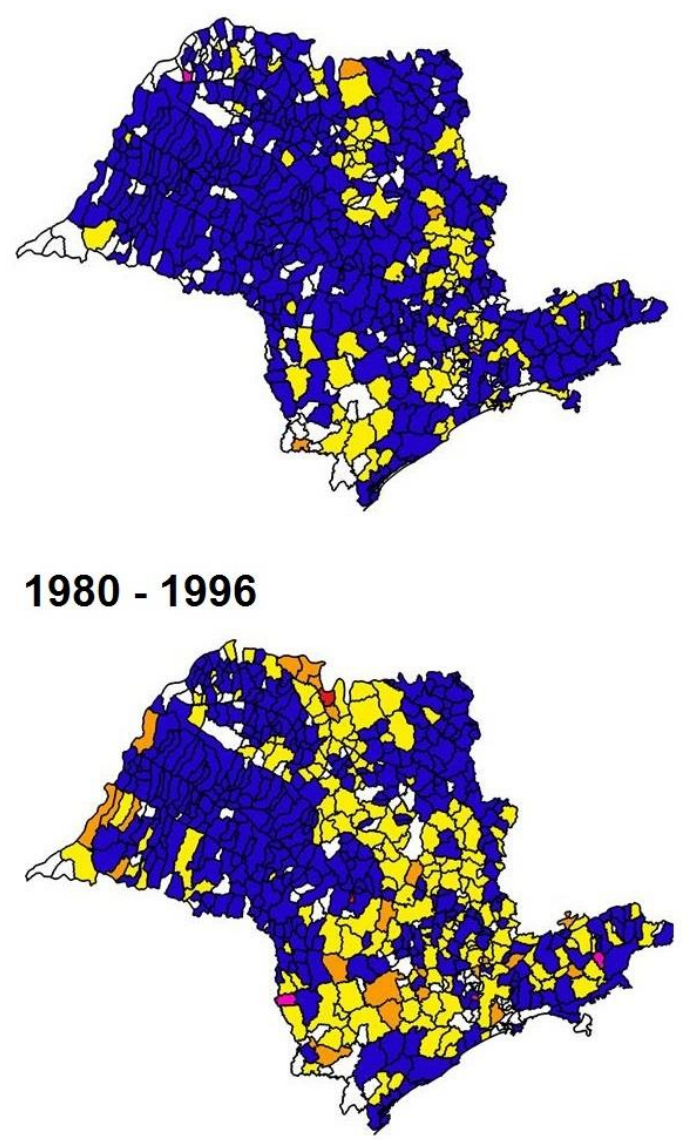
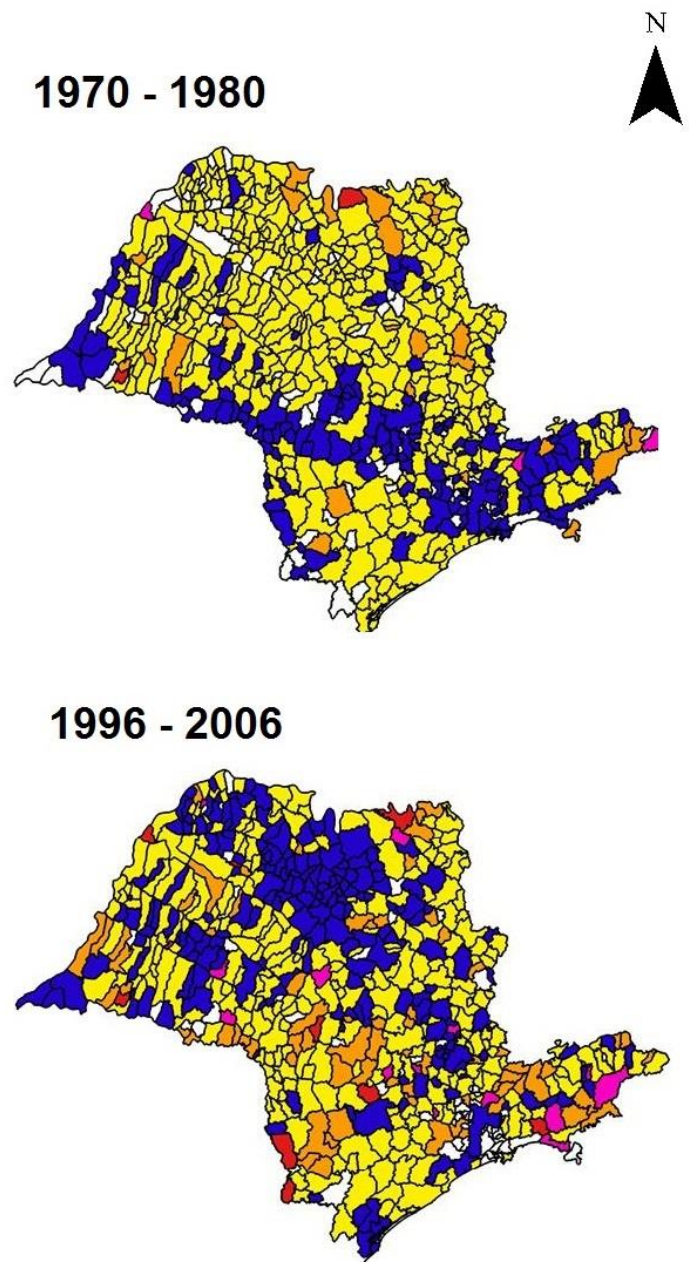

\section{Perennial crops (ratio)}
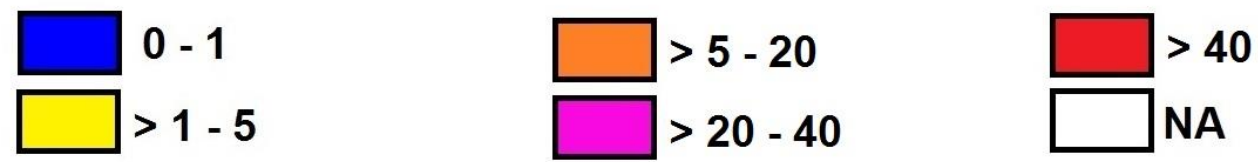

FIGURE A1.6 Perennial crop ratio at the municipality-scale for São Paulo state calculated for the intervals 1960-1970, 1970-1980, 1980-1996 and 1996-2006. Perennial crop ratio was calculated by dividing the perennial crop percentage in one census by perennial crop percentage in the previous census (e.g. values in 1970 / values in 1960). Ratio values greater than 1 (one) indicate that perennial crops increased over the census interval and values lower than 1 (one) indicate that it decreased. Municipality boundaries are shown in black. (NA) Missing values. 

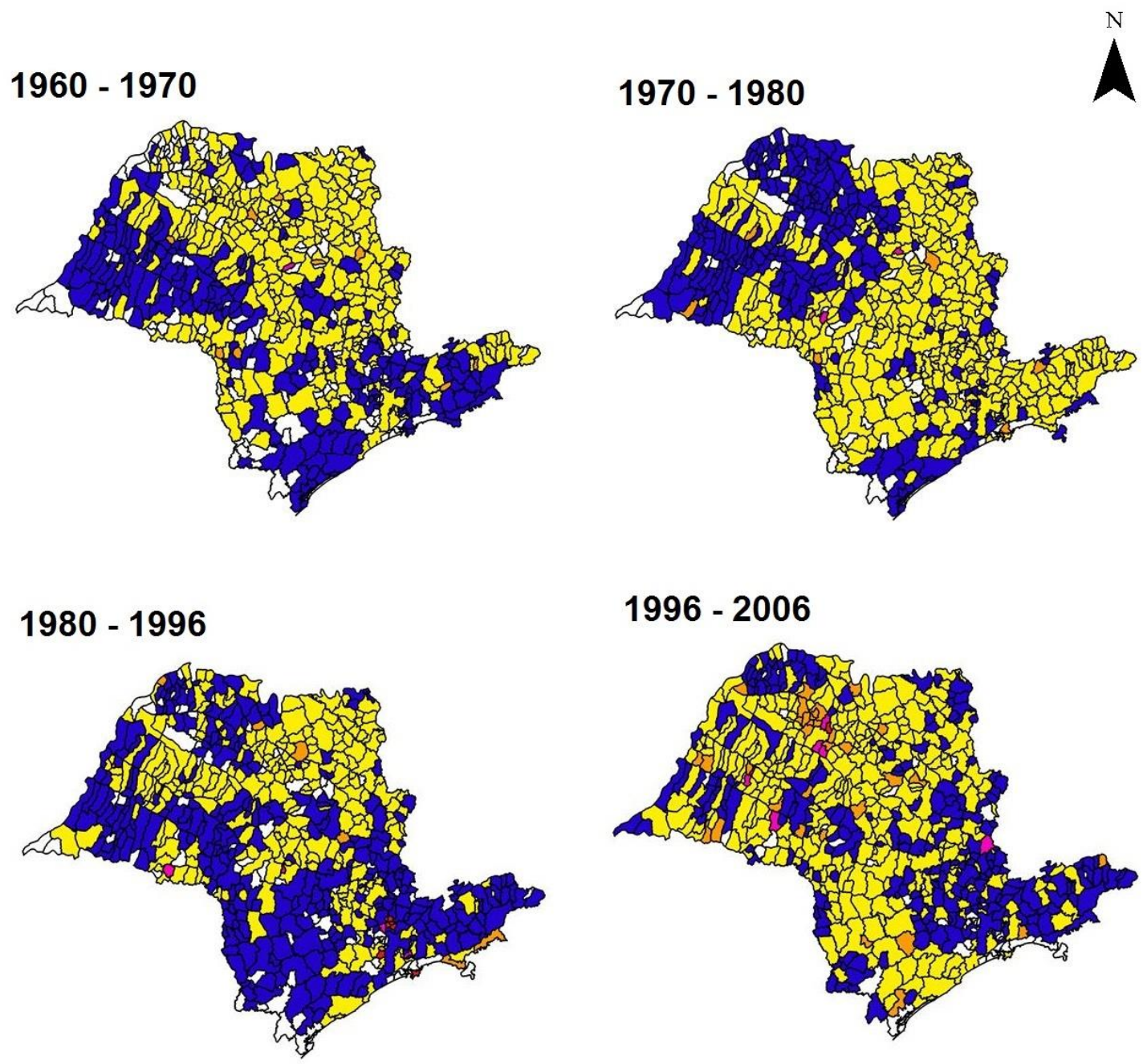

\section{Annual crops (ratio)}
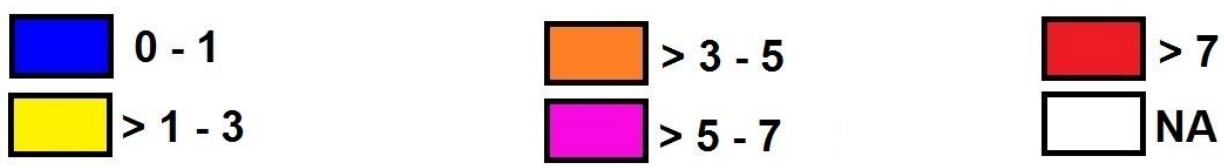

FIGURE A1.7 Annual crop ratio at the municipality-scale for Sao Paulo state calculated for the intervals 1960-1970, 1970-1980, 1980-1996 and 1996-2006. Annual crop ratio was calculated by dividing the annual crop percentage in one census by annual crop percentage in the previous census (e.g. values in 1970 / values in 1960). Ratio values greater than 1 (one) indicate that annual crops increased over the census interval and values lower than 1 (one) indicate that it decreased. Municipality boundaries are shown in black. (NA) Missing values. 

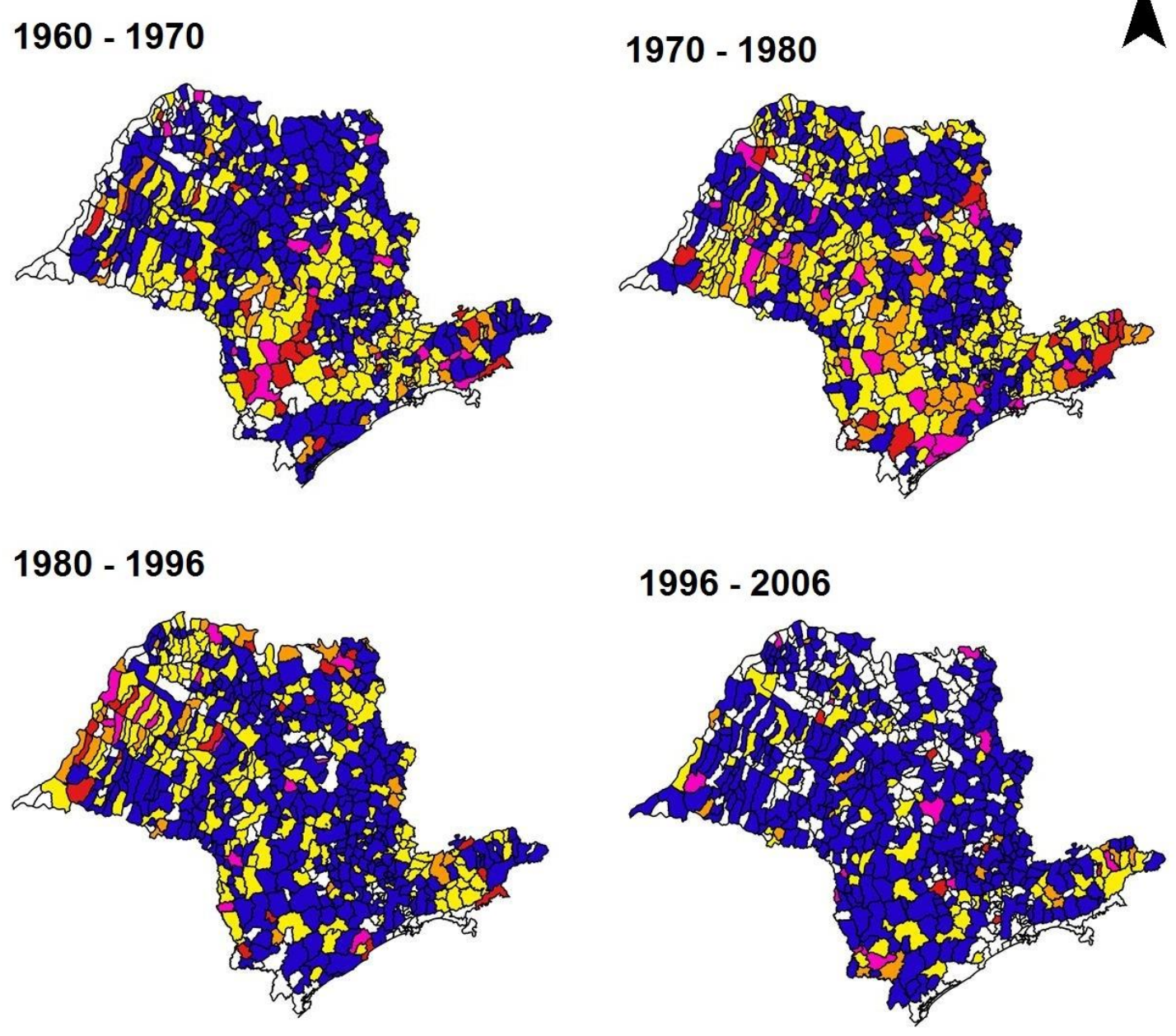

\section{Exotic tree plantation (ratio)}
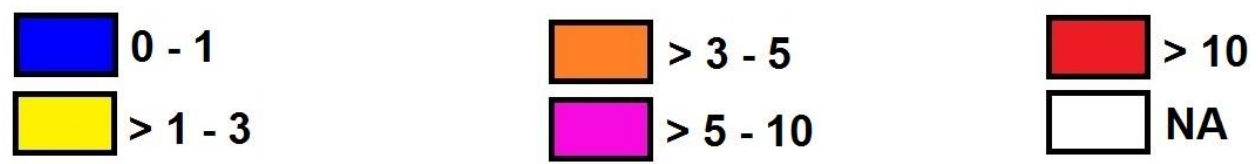

FIGURE A1.8 Exotic tree plantation ratio at the municipality-scale for São Paulo state calculated for the intervals 1960-1970, 1970-1980, 1980-1996 and 1996-2006. Exotic tree plantation ratio was calculated by dividing the percentage of exotic tree plantation in one census by the percentage of exotic tree plantation in the previous census (e.g. values in 1970 / values in 1960). Ratio values greater than 1 (one) indicate that exotic tree plantation increased over the census interval and values lower than 1 (one) indicate that it decreased. Municipality boundaries are shown in black. (NA) Missing values 

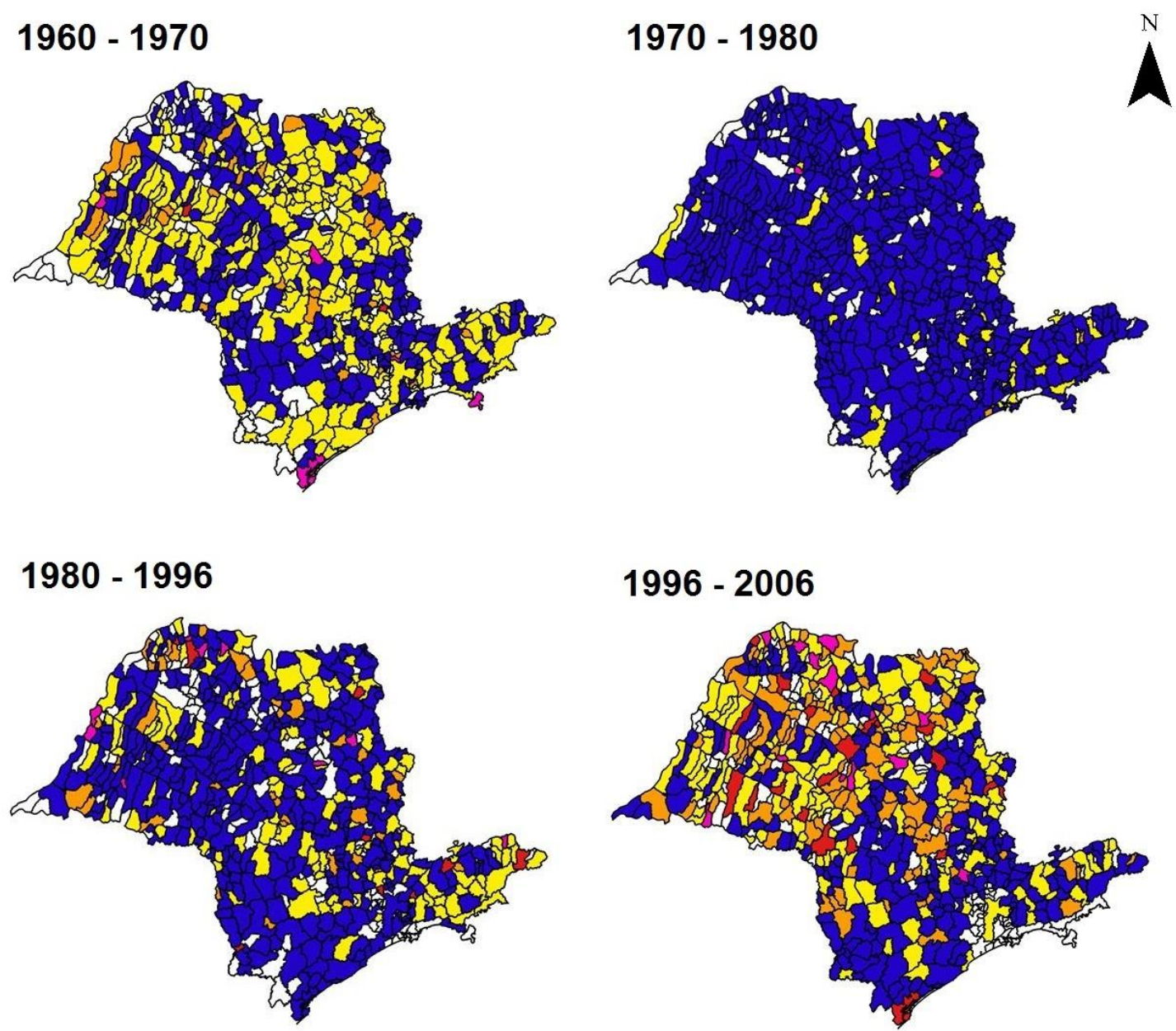

\section{Uncultivated land (ratio)}
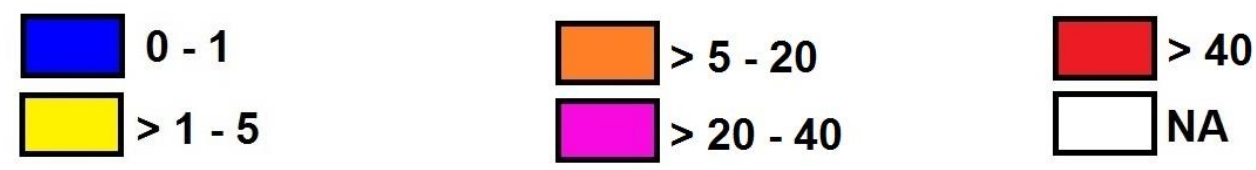

FIGURE A1.9 Uncultivated land ratio at the municipality-scale for São Paulo state calculated for the intervals 1960-1970, 1970-1980, 1980-1996 and 1996-2006. Uncultivated land ratio was calculated by dividing the uncultivated land percentage in one census by uncultivated land percentage in the previous census (e.g. values in 1970 / values in 1960). Ratio values greater than 1 (one) indicate that uncultivated land increased over the census interval and values lower than 1 (one) indicate that it decreased. Municipality boundaries are shown in black. (NA) Missing values. 


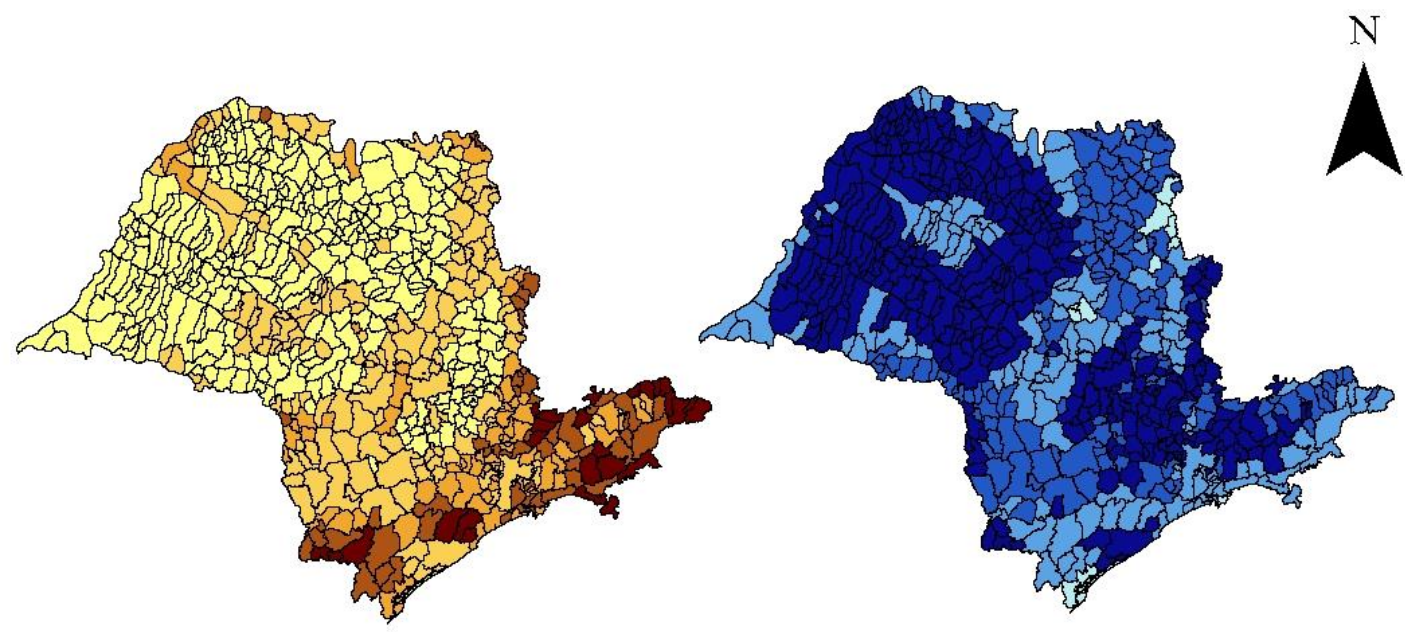

Mean slope degree (\%)

Soil water retention capacity $(\mathrm{mm})$
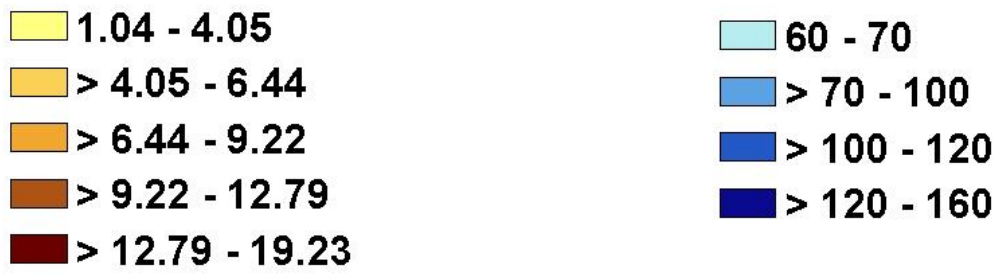

FIGURE A1.10 Soil water retention capacity and mean slope degree at the municipality-scale for the state of São Paulo. Municipality boundaries are shown in black. 